\title{
Prevention of multiple system atrophy using human bone marrow-derived mesenchymal stem cells by reducing polyamine and cholesterol-induced neural damages
}

\author{
Kyung-Ran Park ${ }^{1 \dagger}$, Chul Ju Hwang ${ }^{2 \dagger}$, Hyung-Mun Yun ${ }^{1 \dagger}$, In Jun Yeo ${ }^{2}$, Dong-Young Choi ${ }^{3}$, Pil-Hoon Park ${ }^{3}$, \\ Hyung Sook Kim ${ }^{4}$, Jung Tae Lee ${ }^{4}$, Young Suk Jung ${ }^{5}$, Sang-Bae Han ${ }^{2}$ and Jin Tae Hong ${ }^{2^{*}}$
}

\begin{abstract}
Background: Multiple system atrophy (MSA) is a sporadic neurodegenerative disorder of unknown etiology, but is closely associated with damage to dopaminergic neurons. MSA progression is rapid. Hence, long-term drug treatments do not have any therapeutic benefits. We assessed the inhibitory effect of mesenchymal stem cells (MSCs) on double-toxin-induced dopaminergic neurodegenerative MSA.

Results: Behavioral disorder was significantly improved and neurodegeneration was prevented following MSC transplantation. Proteomics revealed lower expression of polyamine modulating factor-binding protein 1 (PMFBP1) and higher expression of 3-hydroxymethyl-3-methylglutaryl-CoA lyase (HMGCL), but these changes were reversed after MSC transplantation. In the in vitro study, the 6-OHDA-induced effects were reversed following co-culture with MSC. However, PMFBP1 knockdown inhibited the recovery effect due to the MSCs. Furthermore, HMGCL expression was decreased following co-culture with MSCs, but treatment with recombinant HMGCL protein inhibited the recovery effects due to MSCs.
\end{abstract}

Conclusions: These data indicate that MSCs protected against neuronal loss in MSA by reducing polyamine- and cholesterol-induced neural damage.

Keywords: Cholesterol, MSC, Multiple system atrophy (MSA), Polyamines

\section{Background}

Multiple system atrophy (MSA) is an adult-onset, sporadic, rapidly progressive, multisystem, neurodegenerative fatal disease of undetermined etiology. The neuropathological hallmark of MSA is cell loss in the striatonigral region of the brain [1]. Upon pathological examination, MSA exhibits striatonigral and olivopontocerebellar degeneration and bone marrow destruction [2]. In clinical

\footnotetext{
* Correspondence: jinthong@chungbuk.ac.kr

${ }^{\dagger}$ Kyung-Ran Park, Chul Ju Hwang and Hyung-Mun Yun contributed equally to this work

${ }^{2}$ College of Pharmacy and Medical Research Center, Chungbuk National University, 194-31, Osongsangmyeong1-ro, Heungdeok-gu, Cheongju, Chungbuk 361-951, Republic of Korea

Full list of author information is available at the end of the article
}

settings, autonomic failure, parkinsonism, and cerebellar ataxia were observed in such cases [1]. The doubletoxin-induced MSA model was first proposed in 1996. This model showed dopaminergic neurodegeneration following injections of 6-hydroxydopamine hydrochloride (6-OHDA) into the medial forebrain bundle, as well as ipsilateral excitotoxic striatal degeneration following injections of quinolinic acid (QA) [3]. The significant loss of dopaminergic neuronal cells, induced by the two toxins, leads to dopamine deficiency, which can consequently result in behavioral abnormalities.

Mesenchymal stem cells (MSCs) are multipotent stem cells that are capable of self-renewal and differentiation into a wide range of tissues [4]. MSCs exhibit higher 
proliferative capacity and safety [5, 6], and demonstrate non-invasive and ethically non-problematic availability [7]. Recently, several studies have described the applications of MSCs derived from adipose stem cells and bone marrow for neural disorders [8, 9]. Moreover, MSC grafts have demonstrated the potential for re-innervation of the striatum and amelioration of behavioral deficits in animal models of Parkinson's disease (PD) [10].

Recently, the transplantation of MSCs into the brains of transgenic models of Alzheimer's disease has been shown to alleviate symptoms [11-13]. MSCs also play various roles in the body and cellular environment, particularly in the maintenance of other cells [14]. Several in vitro and in vivo studies have shown that MSCs possess immunoregulatory properties. In vitro studies suggest that MSCs can inhibit the immune response and can release various soluble factors that might be involved in immunosuppressive activity [15-17]. Recent in vivo studies also demonstrated that MSC transplantation decreases the production of inflammatory cytokines and genes $[18,19]$. These studies suggest that the anti-inflammatory and immunosuppressive action of MSCs is one possible mechanism underlying those protective effects. These properties of MSC may be useful in the treatment of several human neuronal diseases. Eleven MSA patients who underwent MSC transplantation intra-arterially for 3 months demonstrated a delay in the progression of neurological deficits [20]. Other human clinical trials have suggested that MSCs are also effective in neurodegenerative diseases such as PD [21] and amyotrophic lateral sclerosis [22, 23]. MSCs transplanted into the sublateral ventricular zone via stereotaxic surgery improved the disease status of PD patients [21]. The administration of MSCs into the hippocampus via stereotactic injection was feasible, safe, and welltolerated in nine patients with Alzheimer's disease (AD) [24]. At present, approximately 17 registered clinical trials are assessing the use of MSC therapy for MS treatment (http://www.clinicaltrials.gov/).

The increased levels of polyamines in the brain are associated with neurodegenerative diseases such as PD. Polyamines can induce DNA damage and can lead to cell death [25]. In fact, increased polyamine synthesis has been observed following inflammation [26]. A recent study showed that treatment with lipopolysaccharide (LPS) increased the synthesis of polyamines in cultured microglia [27]. A high level of polyamines consequently led to the accumulation of pro-inflammatory cytokines and chemokines such as TNF- $\alpha$ and CCL2. However, the inhibition of polyamine synthesis through the injection of a specific inhibitor prevented the induction of CCL2 expression by LPS [27]. Moreover, the bacterial infection has been demonstrated to increase the expression and activity of polyamine biosynthetic enzymes
[28]. However, the LPS-induced neurodegeneration was reduced in mice with inhibited polyamine synthesis [29]. Polyamines are converted into putrescine by spermidine/ spermine N1-acetyltransferase (SSAT1), which is expressed at a lower level in patients with PD. Polyamine modulating factor-binding protein 1 (PMFBP1) can enhance the catabolism and recycling of polyamines, thereby lowering levels of spermidine and spermine [30]. Thus, a strategy for lowering polyamine levels through the upregulation of PMFBP1 expression has received considerable interest in the amelioration of neurodegenerative diseases.

HMG-CoA lyase (HMGCL) is a mitochondrial matrix protein from the HMG-CoA lyase family of proteins [31]. Acetyl CoA acts as the precursor in the first stage of cholesterol synthesis. Recent studies have shown that cholesterol can exacerbate neurodegenerative pathology [32-36]. Moreover, studies on transgenic mouse models of $\mathrm{AD}$ indicated that high cholesterol levels can increase AD-pathology hallmarks such as amyloid levels, Tau phosphorylation, and behavioral deficits [33, 35, 37]. Some other prospective studies have found that high serum cholesterol levels may increase the risk of ischemic stroke [38]. Furthermore, recent studies have also shown that excess cholesterol accumulation induces the secretion of pro-inflammatory cytokines and stimulates macrophage recruitment [39]. In vitro studies have shown that cholesterol overload can induce endoplasmic reticulum stress and trigger the unfolded protein response, thus resulting in the activation of both c-Jun Nterminal kinases and ІкB kinase, which are mediators of inflammatory cytokine production. High-cholesterol diets reportedly exacerbate various inflammatory diseases [40, 41]. In the brain, a high cholesterol diet increased oxidative stress in the hippocampus [42] and cortex [43], and also has been shown to elevate the expression of pro-inflammatory cytokines in the hippocampus of 9- to 11-month-old rats [44].

MSCs also regulate the expression of various genes or proteins during the development stage, so it can be used to treat many diseases. MSCs differentiate into adipocytes and express various genes, such as chitinase 3-like 1 (cartilage glycoprotein-39; CHI3L1), retinoic acid receptor responder (tazarotene induced 1; RARRES1), and immunoglobulin domain (Ig) [45]. Moreover, rats with MSC transplantation showed decreased expression of glial fibrillary acidic protein expression (GFAP) and oligodendroglial cell maturation [46]. These data indicate that MSCs may not only directly influence neuronal disease via self-renewal, but may also regulate gene or protein expression related to the inflammation and immune system. However, the direct role and mechanism, particularly the signaling mechanisms, of MSCs remain unclear. 
In the present study, we aimed to assess whether the transplantation of human-derived MSCs could have beneficial effects in a double-toxin-induced MSA rat model. Moreover, we assessed the signaling-based mechanisms underlying the neuro-protective effects of MSCs.

\section{Materials}

The present study conformed to the National Institute of Toxicological Research of the Korea Food and Drug Administration guidelines for the humane care and use of laboratory animals, and all the experimental animal procedures were performed strictly in accordance with the protocol approved by Ethical Committee, IACUC of Chungbuk National University (approval number CBNUA-144-1001-01).

\section{Animal experiments}

A total of 60 adult male Wistar rats weighing 200-250 g were purchased from DBL (Seoul, Korea), and were maintained in accordance with the guidelines of the National Institute of Toxicological Research and Korea Food and Drug Administration for the humane care and use of laboratory animals. Animals were housed in a room that was automatically maintained at $21-25^{\circ} \mathrm{C}$, with a relative humidity of $45-65 \%$ and controlled $12-\mathrm{h}$ light/dark cycle. All experimental procedures in the present study were approved by the IACUC of Chungbuk National University (approval number CBNUA-1441001-01).

To induce MSA, the rats were randomly allocated to 6 groups ( $n=10$ each). Group 1 (control group) received saline, and group 2 (double-toxin group) received both QA and 6-OHDA. Groups 3 and 4 received MSC transplantation via intra-arterial (IA) injection (group 3, $1.2 \times$ $10^{5}$; group 4, $6 \times 10^{5}$ ), and groups 5 and 6 received MSC transplantation via intrathecal (IT) injection (group 5, $1.2 \times 10^{5}$; group $6,6 \times 10^{5}$ ) after double-toxin induction.

\section{Lesion surgery}

Rats were anesthetized with $40 \mathrm{mg} / \mathrm{kg}$ sodium pentobarbital isoflurane and placed in a stereotactic frame (Narishige, Japan). QA (Sigma) was dissolved at a concentration of 5 $\mathrm{mg} / \mathrm{mL}$ in $1 \mathrm{M} \mathrm{NaOH}$, followed by $0.1 \mathrm{M}$ phosphatebuffered saline (PBS), and the $\mathrm{pH}$ was adjusted to 7.4. A total dose $(5 \mu \mathrm{g} / \mathrm{mL}$; equivalent to $90 \mathrm{nmol})$ was injected into each animal. Furthermore, 6-OHDA (Sigma) was dissolved at a concentration of $5 \mathrm{mg} / \mathrm{mL}$ in $0.9 \% \mathrm{NaCl}$ with $0.2 \%$ ascorbic acid, and a total dose of $10 \mu \mathrm{g}$ in $10 \mu \mathrm{L}$ was injected in each animal. The unilateral stereotactic injection site included the right lateral striatum, which receives dense projections from the primary motor cortex and dopaminergic innervation exclusively from the nigra [47-49]. The coordinates were measured anterior and lateral to the bregma and vertical to the dura, with the tooth bar set at
$3.3 \mathrm{~mm}$ below the interaural line. The coordinates of the lesion site were: anterior $-5,0 \mathrm{~mm}$; lateral $-5,3.5 \mathrm{~mm}$; and vertical-5, $5.5 \mathrm{~mm}$, according to the Paxinos and Watson atlas. The toxins were infused at a rate of $5 \mu \mathrm{L} / \mathrm{min}$ through a 29-gauge stainless-steel cannula, attached via a polyethylene tubing to a glass syringe mounted in a Harvard microdrive pump. For each track, the cannula was initially placed stereotactically at the lower depth and left in place $5 \mathrm{~min}$ before the infusion. The cannula was maintained in place for an additional $5 \mathrm{~min}$ to allow for diffusion of the toxin or vehicle before it was slowly withdrawn and rinsed with distilled water prior to the second injection procedure. The wound was then cleaned and sutured, and the rat was allowed to recover. No additional postoperative care was required.

\section{Isolation and expansion of MSCs}

MSCs derived from human patient bone marrow were obtained from Corestem Inc. (Seoul, Republic of Korea). In brief, bone marrow was aspirated from the posterior iliac crest of healthy donors, and mononuclear cells were collected by density gradient methods. The mononuclear cells were cultured in CSBM-A06 medium (Corestem Inc.) containing $10 \%$ fetal bovine serum (Gibco, Grand Island, NY, USA), $2.5 \mathrm{mM} \mathrm{L-glutamine,} \mathrm{and} \mathrm{penicillin/}$ streptomycin (WelGene, Gyeongsangbuk-do, Republic of Korea) in an incubator at $37^{\circ} \mathrm{C}$ and $5 \% \mathrm{CO} 2$ for $3-5$ passages. After washing out non-adherent cells, the adherent cells retained the canonical phenotype of MSCs $\left(\mathrm{CD} 29^{+} \mathrm{CD} 44^{+} \mathrm{CD} 73^{+} \mathrm{CD} 105^{+} \mathrm{CD} 90^{+} \mathrm{CD} 34^{-} \mathrm{CD} 45^{-} \mathrm{HLA}^{--}\right.$ $\mathrm{DR}^{-}$) and were used in the experiments. The study was approved by the Institutional Review Board of Hanyang University Hospital.

\section{Rotarod test}

Motor performance and coordination were examined using the Rotarod treadmill (MED Associates Inc., St. Albans, VT, USA), which consisted of a 5-cm-diameter cylindrical treadmill connected to a computer-controlled stepper motor, as described previously [50]. The time at which the animal falls off the rotating drum was detected by individual sensors, and the time spent by the animal on the treadmill (in seconds) was automatically recorded. Rats were trained for 2 consecutive days before the double-toxin injections were given, in acceleration mode $(5-30 \mathrm{rpm})$ over $5 \mathrm{~min}$. The training was repeated at a fixed speed $(15 \mathrm{rpm})$ until the rats were able to stay on the rod for at least $300 \mathrm{~s}$. If the animals did not pass the training, they were excluded from further experiments.

\section{Gait test}

Stride length was measured according to the method of Fernagut et al. [51]. In brief, after their forelimbs and 
hindlimbs were painted with ink, the animals were placed on a bright runway $(9 \mathrm{~cm}$ wide and $90 \mathrm{~cm}$ long, with $20 \mathrm{~cm}$ high walls) and were allowed to run towards a dark goal box $(40 \times 30 \times 20 \mathrm{~cm})$. Rats were subjected to two training trials for acclimatization to the environment. A single test trial was performed and stride length was measured as the distance between successive paw prints. Data are presented as the average value of five strides for each animal.

\section{Grip strength}

The maximal muscle strength of the forelimbs was measured by using an isometric transducer attached to a 3mm-diameter metal bar (Ugo Basile). For the measurement of forelimb grip strength, each mouse gripped the bar with its forelimbs and was then slowly pulled backward until it released the metal bar. The transducer measured the maximal grip strength in grams. Five trials were performed in each testing session, and the maximum value was calculated.

\section{Brain tissue collection and preservation}

After behavioral tests were conducted, the animals were perfused with PBS after being anesthetized by inhaled sodium pentobarbital isoflurane. The brains were immediately removed from the skull, and the cortex and hippocampus were dissected on ice. All the brain tissues were immediately stored at $-80^{\circ} \mathrm{C}$ until biochemical assays could be conducted.

\section{Neuronal cell and microglial BV-2 cell culture}

The Sprague-Dawley rats were maintained in accordance with the policy of the National Institute of Toxicological research, which was in accordance with the Korea Food and Drug Administration's guideline for the care and use of laboratory animals. Sprague-Dawley rats weighing 200-300 g were housed under $12 \mathrm{~h}$ light/dark cycles at $23^{\circ} \mathrm{C}$ and $60 \pm 5 \%$ humidity. All animals had free access to food (Samyang Foods, Seoul, Republic of Korea) and water. Cerebral cortical cells were isolated from neonatal rat brains (day 1$)$ in PBS $(0.1 \mathrm{~mol})$. Briefly, cerebral cortices were removed and incubated for $15 \mathrm{~min}$ in $\mathrm{Ca}^{2+}$ and $\mathrm{Mg}^{2+}$-free Hanks' balanced saline solution (Life Technologies) containing $0.2 \%$ trypsin. Cells were dissociated by trituration and plated into polyethyleneiminecoated plastic or glass-bottomed culture dishes containing minimum essential medium with Earle's salts supplemented with $10 \%$ heat-inactivated fetal bovine serum, 2 $\mathrm{mM} \mathrm{L}$-glutamine, $1 \mathrm{mM}$ pyruvate, $20 \mathrm{mM} \mathrm{KCl}, 10 \mathrm{mM}$ sodium bicarbonate, and $1 \mathrm{mM}$ Hepes (pH 7.2). Following cell attachment (3-6 h after plating), the culture medium was replaced with a neurobasal medium containing B27 supplements (Life Technologies). The cells were cultured in the neuronal cell culture medium for 3 days, and then further cultured in a neuronal cell culture medium (NCM) with or without $20 \%$ astrocyte culture media (ACM). Experiments were performed with 4 to 6day-old cultures; more than $90 \%$ of the cells in these cultures were neurons, and the remainder were astrocytes, as judged by the cell morphology and by immunostaining with antibodies against neurofilaments and glial fibrillary acidic protein. Microglial BV-2 cell cultures were prepared as previously described [52]. The BV-2 cells were incubated in the culture medium in a humidified incubator at $37^{\circ} \mathrm{C}$ and $5 \% \mathrm{CO} 2$.

\section{Sample preparation for two-dimensional electrophoresis (2-DE)}

Brain samples were homogenized in liquid nitrogen, after which the sonicated tissues were lysed in buffer (7 M urea, $2 \mathrm{M}$ thiourea, 4\% w/v CHAPS, 2.5\% DTT buffer, and protease inhibitor [Roche, Cat. no. 11697498001]). The sample mixtures were subsequently centrifuged at $45,000 \times \mathrm{g}$ at $4{ }^{\circ} \mathrm{C}$ for $1 \mathrm{~h}$, after which the protein concentrations were determined by the Bradford protein assay (Bio-Rad, Hercules, CA, USA). In this process, a brain sample was generated from a pool of 6 animals in each group. The pooled samples were analyzed three times.

\section{2-DE analysis}

One-dimensional isoelectric focusing (IEF) was performed using a 24-cm-immobilized $\mathrm{pH}$ gradient (IPG) strips (GE Healthcare, Uppsala, Sweden) in a $\mathrm{pH}$ range of 4.0-7.0 (non-linear). Protein $(120 \mu \mathrm{g})$ was loaded in a total volume of $450 \mu \mathrm{L}$. After rehydration for $13 \mathrm{~h}$, the strips were focused at $30 \mathrm{~V}$ for $2 \mathrm{~h}, 100 \mathrm{~V}$ for $2 \mathrm{~h}, 200 \mathrm{~V}$ for $1 \mathrm{~h}, 500 \mathrm{~V}$ for $1 \mathrm{~h}, 1000 \mathrm{~V}$ for $1 \mathrm{~h}$, and finally at 8000 $\mathrm{V}$ for $22 \mathrm{~h}$ to obtain $\sim 100,000 \mathrm{VHr}$ (IPGphor; GE Healthcare). Once IEF was completed, the strips were equilibrated in $6 \mathrm{M}$ urea containing $20 \%$ glycerol, $2 \%$ sodium dodecyl sulfate (SDS), and $0.01 \%$ bromophenol blue, with $10 \mathrm{mM}$ tributyl phosphine. Two-dimensional SDS-PAGE was performed using 14\% linear gradient acrylamide gels in an Ettan DALT system (GE Healthcare). Proteins were visualized by staining with Coomassie brilliant blue G-250 (Bio-Rad). Only the filtered spots that exceeded an intensity threshold involving a 2 -fold increase or decrease among the 3 groups were studied further, whereas the threshold regulation factor for the significance level was set at $P \leq 0.05$. Finally, the spots showing significant changes in expression were subsequently identified by mass spectrometry.

\section{Identification of protein spots}

The stained gels were scanned with a GS800 densitometer (Bio-Rad) and analyzed using Image master ${ }^{\text {Tx }}$ (Swiss Institute of Bioinformatics, Geneva, Switzerland). The spots were digested using trypsin, after which the 
supernatant peptide mixtures were loaded onto a Poros R2 column (Applied Biosystems, Foster City, CA, USA) that had been washed with the following solutions: (i) $70 \%$ acetonitrile in 5\% formic acid, (ii) 100\% acetonitrile, and (iii) 5\% formic acid. Peptides were eluted using $5 \mu \mathrm{L}$ of $\alpha$-cyano-4-hydroxycinnamic acid and were analyzed with a matrix-assisted laser desorption/ionization timeof-flight (MALDI-TOF) mass spectrometer (Voyager DE-PRO; Applied Biosystems). For protein identification, the masses of the peptides determined by MALDI-TOF were matched with theoretical peptides in the NCBI (http://www.ncbi.nih.gov/) database using the MASCOT (http://www.matrixscience.com) and ProFound programs (http://prowl.rockefeller.edu).

\section{Western blot analysis}

Cells and each area of the brain tissue were homogenized and lysed following $30 \mathrm{~min}$ incubation on ice. The lysates were centrifuged at $15,000 \mathrm{rpm}$ for $15 \mathrm{~min}$. An equal amount of total protein $(20 \mathrm{mg})$ isolated from brain tissues was resolved on $10 \%$ or $12 \%$ SDS-PAGE gels and then was transferred to a nitrocellulose membrane (Hybond ECL; Amersham Pharmacia Biotech, Piscataway, NJ, USA). Blots were blocked for $1 \mathrm{~h}$ at room temperature with $5 \%(\mathrm{w} / \mathrm{v})$ nonfat dried milk in Trisbuffered saline with Tween-20 (TBST) containing 10 $\mathrm{mM}$ Tris (pH 8.0), $150 \mathrm{mM} \mathrm{NaCl}$, and $0.05 \%$ Tween-20. After a short wash in TBST, the membranes were immunoblotted with the following antibodies: rabbit polyclonal anti-tyrosine hydroxylase $(\mathrm{TH})$, anti-caspase-3 (1:1000 dilution; Cell Signaling Technology, Inc. Beverly, MA, USA), anti-COX-2 (1:1000 dilution; Novus Biologicals, Littleton, CO, USA), anti-PMFBP1 (1:1000 dilution; MyBioSource, San Diego, CA, USA), anti-HMGCL (1: 1000 dilution; Abcam, Cambridge, UK), goat polyclonal anti-IBA1 (1:1000 dilution; Abcam, Cambridge, UK), mouse monoclonal anti-BAX, anti-GFAP (1:500 dilution; Santa Cruz Biotechnology Inc., Dallas, TX, USA), or mouse monoclonal anti-iNOS (1:1000 dilution; Cell Signaling Technology, Inc. Beverly, MA, USA). The blots were then incubated with the corresponding horseradish peroxidase-conjugated anti-rabbit (1:5000 dilution; Santa Cruz Biotechnology Inc.), anti-goat (1:10000 dilution; Santa Cruz Biotechnology Inc.), and anti-mouse IgG (1: 2000 dilution; Santa Cruz Biotechnology Inc.). Immunoreactive proteins were detected by enhanced chemiluminescence and subjected to densitometric analysis using MyImage (SLB, Seoul, Republic of Korea), and quantified in Labworks 4.0 software (UVP Inc., Upland, CA, USA) [53].

\section{Immunohistochemistry}

While under general anesthesia, the rats received intracardiac perfusion with $50 \mathrm{~mL}$ of saline. The brains were fixed in formalin and paraffin-embedded for examination. Tissue sections, $5 \mu \mathrm{m}$ thick, were used for immunohistochemical examinations. Paraffin-embedded sections were deparaffinized and rehydrated, washed in distilled water, and then subjected to heat-mediated antigen retrieval treatment. Endogenous peroxidase activity was quenched via incubation in $1 \%$ hydrogen peroxide in methanol for $30 \mathrm{~min}$, followed by clearing with PBS for $5 \mathrm{~min}$. The sections were blocked for $30 \mathrm{~min}$ with $3 \%$ normal horse/goat serum diluted in PBS. The sections were then blotted and incubated with primary rabbit anti-TH (1:200 dilution; Cell Signaling Technology, Inc. Beverly, MA, USA), goat anti-IBA1 (1:200 dilution; Abcam, Cambridge, UK) and mouse anti-GFAP (1: 200 dilution; Santa Cruz Biotechnology Inc., Dallas, TX, USA) in blocking serum overnight at $4{ }^{\circ} \mathrm{C}$. The next day, the slides were washed three times for $5 \mathrm{~min}$ each in PBS and incubated in biotinylated anti-rabbit, anti-goat, or anti-mouse antibodies for $2 \mathrm{~h}$, and then washed again in PBS. The avidin-biotin-peroxidase complexes were formed (Vector Laboratories, Inc., Burlingame, CA, USA) and the peroxidase reaction was developed with diaminobenzidine and peroxide. The tissue sections were then counterstained with hematoxylin, mounted with aqua-mount, and evaluated using a light microscope at $\times 200$ magnification (Olympus, Tokyo, Japan) [54].

\section{Analysis of TH-positive neurons and fibers}

The total number of TH-positive cells was counted in sections using the optical fractionator method for unbiased cell counting as described previously with slight modifications [55]. Briefly, every sixth section throughout the entire extent of the substantia nigra was picked, and immunostaining for $\mathrm{TH}$ was performed. The number of TH-positive neurons was counted by using a computer-assisted image analysis system consisting of a Zeiss Axioskop2 Plus photomicroscope equipped with an MS-2000 (Applied Scientific Instrumentation, Eugene, OR, USA) computer-controlled motorized stage, a Sony DXC-390 video camera, a DELL GX260 workstation, and the Optical Fractionator Project module of the BIOQUANT Stereology Toolkit Plug-in for BIOQUANT Nova Prime software (BIOQUANT Image Analysis Corporation, Nashville, TN, USA). The substantia nigra region was observed at low magnification ( $\times 10$ objective) and was outlined by using a set of anatomical landmarks. The cell number was counted at high magnification $(x$ 40 objective). The total number of neurons was automatically calculated by the software. For determining striatal TH-positive fiber density, we picked six striatum-containing sections covering the entire head and tail of the striatum from each animal. To prevent non-specific staining, a blocking step was included. Sections were incubated for $2 \mathrm{~h}$ at room temperature with 
5\% BSA in PBS. Sections were then incubated overnight at $4{ }^{\circ} \mathrm{C}$ with the primary antibody in blocking solution (5\% BSA). TH-positive fiber density was measured by using Bioquant Image Analysis software. All images were converted to a grayscale for standardizing white balance. Each value was corrected for non-specific background by subtracting the optical density of the corpus callosum.

\section{Measurement of cytokine levels}

The lysates of brain tissue were obtained using a protein extraction buffer containing protease inhibitor. IL-1 $\beta$ and IL-6 levels were determined using a specific enzyme-linked immunosorbent assay (ELISA) Kit (ImmunoBiological Laboratories Co., Ltd., Takasaki-Shi, Gunma, Japan). In brief, $100 \mathrm{~mL}$ of the sample was added to the precoated plate and was incubated overnight at $4{ }^{\circ} \mathrm{C}$. After washing each well of the precoated plate with washing buffer, $100 \mathrm{~mL}$ of labeled antibody solution was added, and the mixture was incubated for $1 \mathrm{~h}$ at $4{ }^{\circ} \mathrm{C}$ in the dark. After washing, a chromogen was added, and the mixture was incubated for $30 \mathrm{~min}$ at room temperature in the dark. Finally, the resulting color was assayed at $450 \mathrm{~nm}$ using a microplate absorbance reader (SunriseTM, TECAN, Switzerland) after adding the stop solution.

\section{Measurement of polyamine content}

The polyamine levels in the rat brain were determined using high-performance liquid chromatography. In brief, tissues were sonicated in chilled $0.1 \mathrm{M}$ perchloric acid containing dihydroxybenzylamine as an internal standard. After centrifugation $\left(15,000 \times g, 30 \mathrm{~min}, 4^{\circ} \mathrm{C}\right)$, the supernatant was diluted with the mobile phase $(0.2 \%$ acetic acid in distilled water), and $10 \mu \mathrm{L}$ of sample was isocratically eluted through an $80 \times 4.6 \mathrm{~mm} \mathrm{C18}$ column (Waters Associates, Milford, MA, USA) at a flow rate of $1.5 \mathrm{~mL} / \mathrm{min}$. Polyamines, including spermidine and spermine, were detected using a two-channel electrochemical detector (Waters Associates) at a potential of $1.5 \mathrm{mV}$. The concentrations were normalized by wet tissue weight. The retention times for spermidine and spermine were 9 and $11 \mathrm{~min}$, respectively.

\section{Cholesterol level measurement}

The total cholesterol level was measured using an enzymatic kit obtained from Roche for use with the Cobas Mira Chemstation (Boehringer Mannheim Corp., Germany). This method follows a two-step approach. In the first step, cholesterol is desterified by the action of cholesterol esterase and subsequently exposed to the action of cholesterol oxidase. The second step involves coupling with a chromogen (color-forming compound), which can be measured using a spectrophotometer, wherein the increase in absorbance due to the chromogen at $405 \mathrm{~nm}$ was proportional to the cholesterol concentration in the sample. The amount of total cholesterol was expressed in units of milligrams per deciliter.

\section{TUNEL assay}

DNA fragmentation was examined with terminal deoxynucleotidyl transferase-mediated FITC-dUDP nick-end labeling (TUNEL). TUNEL assays were performed using the In Situ Cell Death Detection Kit (Roche Diagnostics $\mathrm{GmbH}$, Mannheim, Germany) according to the manufacturer's instructions. In brief, after fixation of $25 \mathrm{~mm}$ cryosections with $4 \%$ paraformaldehyde, and treatment with $0.1 \% \mathrm{NaBH}_{4}$ and $0.1 \%$ Triton $\mathrm{X}-100$, the slides were incubated for at least $1 \mathrm{~h}$ with a reaction mixture containing deoxynucleotidyl transferase and FITC-dUDP (Roche, Reinach, Switzerland). For 4',6'-diamidino-2phenylindole dihydrochloride (DAPI) staining, the slides were incubated for $15 \mathrm{~min}$ at room temperature in the dark with a mounting medium for fluorescence containing DAPI (Vector Laboratories). The tissues were then examined via fluorescence microscopy (Leica Microsystems AG, Wetzlar, Germany), and the nuclei were visualized via DAPI staining [56].

\section{Statistical analysis}

The image density was measured using the ImageJ software (Wayne Rasband, National Institutes of Health, Bethesda, MD, USA). Graph data were analyzed using the GraphPad Prism version 4 program (GraphPad Software, Inc., San Diego, CA, USA). Data are presented as mean \pm standard deviation. Statistical significance was assessed using a two-way analysis of variance (ANOVA). A $P$ value of $<0.05$ was considered statistically significant.

\section{Results \\ MSC reduces behavioral disorders in double-toxin- induced MSA rats}

To identify whether MSCs can mitigate behavioral disorders caused by the two toxins in MSA, we performed behavioral tests, including rotarod, gait, and grip strength tests. The tests were performed three trials per day for each group $(n=10)$ to obtain statistical significance. The rotarod test was conducted to assess the coordination capability of the rats. Double-toxin injection significantly decreased the latency of falling from the treadmill. However, a significantly better performance in the rotarod test was observed in rats transplanted with MSCs via IA injection $\left(1.2 \times 10^{5}\right.$ cells, $113.5 \pm 11.27 \mathrm{~s}, F=2.57 ; 6 \times 10^{5}$ cells, $133.6 \pm 7.29 \mathrm{~s}, F=3.45)$ and IT injections $\left(1.2 \times 10^{5}\right.$ cells, $87.1 \pm 19.81 \mathrm{~s}, F=7.11 ; 6 \times 10^{5}$ cells, $141.9 \pm 21.01 \mathrm{~s}$, $F=2.76$ ) (Fig. 1a). Moreover, the grip strength of the forelimb was significantly decreased following double- 
toxin injection $(10.96 \pm 0.98 \mathrm{~s}, F=2.15)$, although this decrease was mitigated via IA MSC transplantation $(1.2 \times$ $10^{5}$ cells, $11.9 \pm 1.34 \mathrm{~s}, F=5.13 ; 6 \times 10^{5}$ cells, $13.7 \pm 1.18$ s, $F=1.83)$ and IT MSC transplantation $\left(1.2 \times 10^{5}\right.$ cells, $11.8 \pm 0.91 \mathrm{~s}, F=2.94 ; 6 \times 10^{5}$ cells, $13.9 \pm 1.01 \mathrm{~s}, F=4.12$, Fig. 1b). In the stride length test, the results showed that the double-toxin injection resulted in shortened forelimb stride length (Fig. 1c) and hindlimb stride length (Fig. 1d). However, the stride length was shortened to a lesser degree in rats with IA MSC transplantation (forelimb $1.2 \times 10^{5}$ cells, $11.7 \pm 0.49 \mathrm{~s}, F=3.62 ; 6 \times 10^{5}$ cells, $13.8 \pm 0.11 \mathrm{~s}, \quad F=1.15$; hindlimb $1.2 \times 10^{5}$ cells, $11.6 \pm$ $0.81 \mathrm{~s}, F=7.13 ; 6 \times 10^{5}$ cells, $\left.12.7 \pm 1.14 \mathrm{~s}, F=5.11\right)$ and IT MSC transplantation (forelimb $1.2 \times 10^{5}$ cells, $11.9 \pm$ $0.74 \mathrm{~s}, F=1.11 ; 6 \times 10^{5}$ cells, $14.1 \pm 0.31 \mathrm{~s}, F=6.09$; hindlimb $1.2 \times 10^{5}$ cells, $11.1 \pm 0.37 \mathrm{~s}, F=2.72 ; 6 \times 10^{5}$ cells, $13.8 \pm 0.99 \mathrm{~s}, F=4.31$ ), as compared to those in doubletoxin-injected rats (forelimb $11.04 \pm 0.83 \mathrm{~s}, F=2.66$, hindlimb $10.2 \pm 0.72 \mathrm{~s}, F=2.73)$.

\section{MSC ameliorates dopaminergic neurodegeneration in double-toxin-induced MSA rats}

To investigate whether the MSC-induced inactivation of astrocytes could prevent dopamine depletion and neuronal cell death, we evaluated the neurotoxicity of double- toxins using western blots and immunohistochemical staining of TH. Immunohistochemical staining for $\mathrm{TH}$ revealed an abundance of TH-positive fibers in the striatum and substantia nigra in the saline-injected group. When the rats were injected with double-toxins, the number of $\mathrm{TH}$-positive neurons was significantly reduced in the substantia nigra. Consistent with this, the density of $\mathrm{TH}$ positive fibers after the double-toxin intoxication was significantly lowered in the striatum (Fig. 2a). However, the population of dopaminergic neurons after double-toxin intoxication was restored in MSC-transplanted rats (Fig. 2a). Consistent with these findings, the double-toxininduced protein expression of $\mathrm{TH}$ in the striatum and substantia nigra was also significantly increased in MSCtransplanted rats, as compared to double-toxin-injected rats (Fig. 2b). We explored whether MSCs could improve dopaminergic neurodegeneration by preventing doubletoxin-induced dopaminergic neuronal cell death. In the striatum and substantia nigra regions of the brain, doubletoxin injection significantly increased apoptotic cell death, as compared to that noted in control rats (striatum, $81.23 \pm 8.75 \%, F=1.24$; nigra, $71.21 \pm 7.63 \%, F=4.11$ ). MSCs inhibited apoptotic cell death in double-toxininjected rats when injected via IA (striatum $1.2 \times 10^{5}$ cells, $72.16 \pm 10.21, \quad F=7.21 ; 6 \times 10^{5}$ cells, $63.2 \pm 7.63 \mathrm{~s}, \quad F=$
A

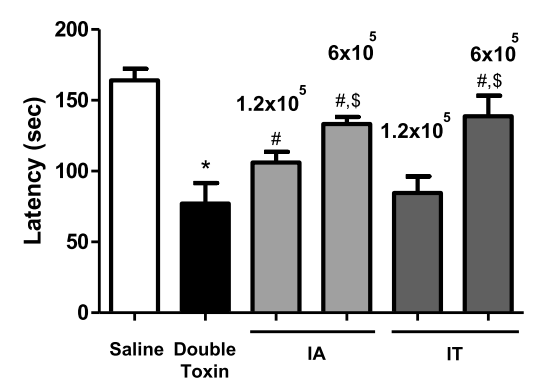

C

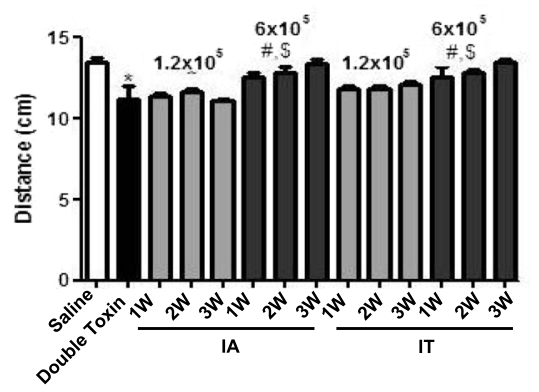

B

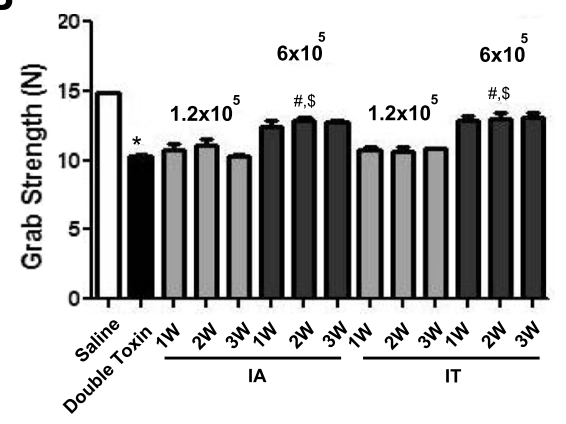

D

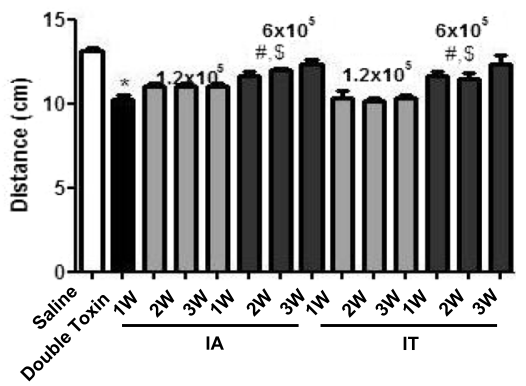

Fig. 1 Mesenchymal stem cell (MSC) transplantation ameliorates double-toxin-induced behavior disorders. The performance on the rotarod test was impaired following the double-toxin injection. However, the impairment was ameliorated in the double-toxin-injected MSC-transplanted group (a). Double-toxin-induced bradykinesia was ameliorated in the double-toxin-injected MSC-transplanted group (b). The stride length of the forelimb (c) and hindlimb (d) was increased to a greater extent following MSC treatment in the double-toxin injection group. Values are presented as mean \pm standard deviation of 10 rats. ${ }^{*} P<0.05$, significant difference vs. the saline-injected group. \#P<0.05, significant difference among the double-toxin-injected group. $\$<0.05$, significant difference between two numbers of the MSC-injected group 


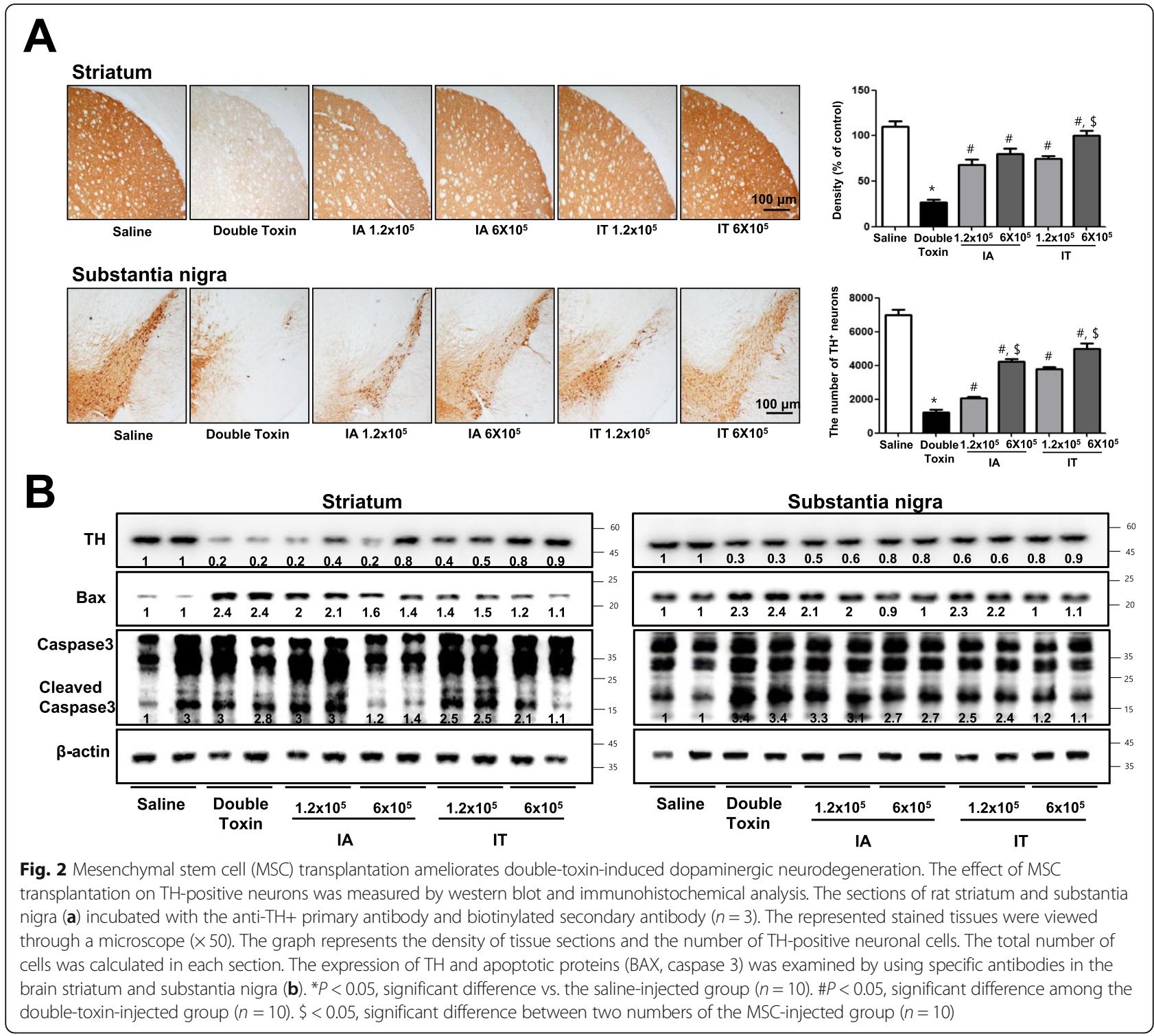

10.04; nigra $1.2 \times 10^{5}$ cells, $66.12 \pm 8.74, F=9.67 ; 6 \times 10^{5}$ cells, $53.27 \pm 8.14, F=4.12$ ) and IT routes (striatum $1.2 \times$ $10^{5}$ cells, $71.12 \pm 3.97, F=3.33 ; 6 \times 10^{5}$ cells, $37.2 \pm 4.48 \mathrm{~s}$, $F=4.17, P<0.05$; nigra $1.2 \times 10^{5}$ cells, $51.74 \pm 9.35, F=$ 11.21; $6 \times 10^{5}$ cells, 29.64 $\pm 6.28, F=4.32$ ) (Supplementary Fig. 1). To determine whether double-toxin injections can induce neuronal cell death, western blotting was used to detect the expression of apoptotic markers (caspase 3 and $\mathrm{BAX}$ ) in the rat brains. Our data indicated that the double-toxin-induced cleavage of caspase 3 , and the expression of BAX in the striatum and substantia nigra were significantly decreased in MSC-transplanted rats (Fig. 2b).

\section{MSC exhibits anti-inflammatory effects in double-toxin-} induced MSA rats

Neuroinflammation is critical to the development of MSA and can be induced through the activation of astrocytes and microglia. To determine whether double-toxin injection can induce neuroinflammation and the activation of astrocytes and microglia, western blotting and immunohistochemistry examinations were used to detect the expression of GFAP (a marker of astrocyte activation) and IBA1 (a marker of microglia activation) in rat brains. Our data showed that the number of reactive cells following immunostaining for GFAP and IBA1 in the striatum and substantia nigra of double-toxin-injected MSC-transplanted rats were significantly lower as compared to those in doubletoxin-injected rats (Fig. 3a). The double-toxin-induced protein expressions of GFAP and IBA1 in the striatum and substantia nigra were also significantly decreased in MSCtransplanted rats (Fig. 3b). Moreover, the double toxininduced protein expressions of inflammatory marker proteins $\mathrm{iNOS}$ and COX2 in the striatum and substantia nigra were also significantly decreased in MSC-transplanted rats 
(Supplementary Fig. 2A). Consistent with these findings, the levels of pro-inflammatory cytokines, IL- $1 \beta$ and IL-6, were significantly decreased in the MSC-transplanted rat striatum and substantia nigra (Supplementary Fig. 2B). In addition, neutrophils were significantly decreased, but WBCs were significantly increased in double-toxin-induced rat blood, but these changes were recovered in MSCtransplanted rat blood (Supplementary Fig. 3A).

\section{Proteomic analysis of total proteins in the brain striatum} To characterize the changes in global protein expression in the brain striatum of three experimental groups (sham control, double-toxin-induced, and stem celltransplanted; IT, $6 \times 10^{5}$ cells), whole proteins extracted from the striatum of three experimental groups were analyzed using 2-DE gels. Computer analysis of the gel images showed good matching in three analytical replicates, including sham-controlled rats, double-toxininduced rats, and MSC-transplanted rats (IT, $6 \times 10^{5}$ ). The 2-DE protein maps of the samples from the three groups are shown in Fig. 4a. Approximately, 350 spots were detected in 1 gel from the brain striatum. The spots that showed significantly different expression were selected for further analysis. In total, six spots were

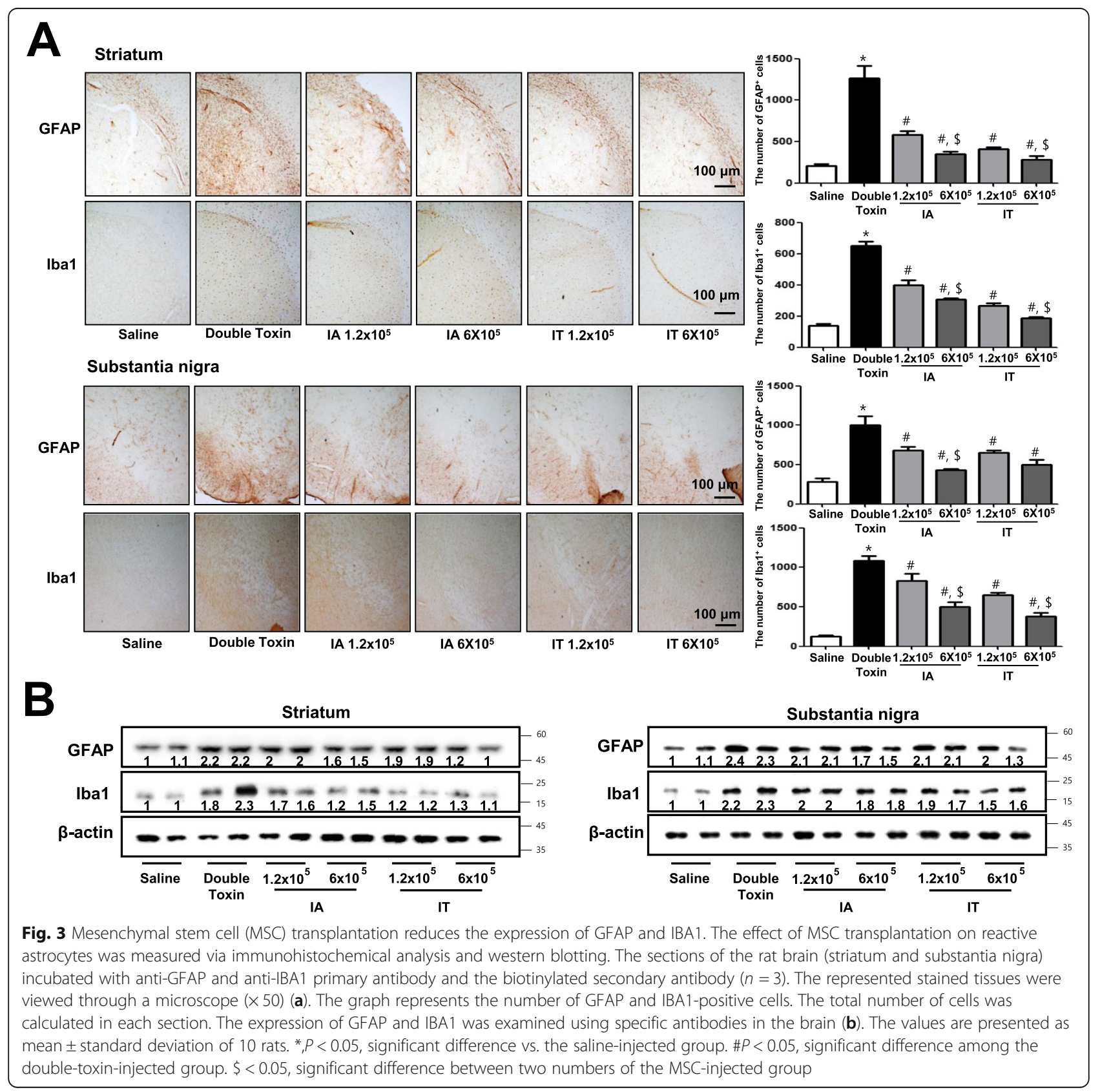




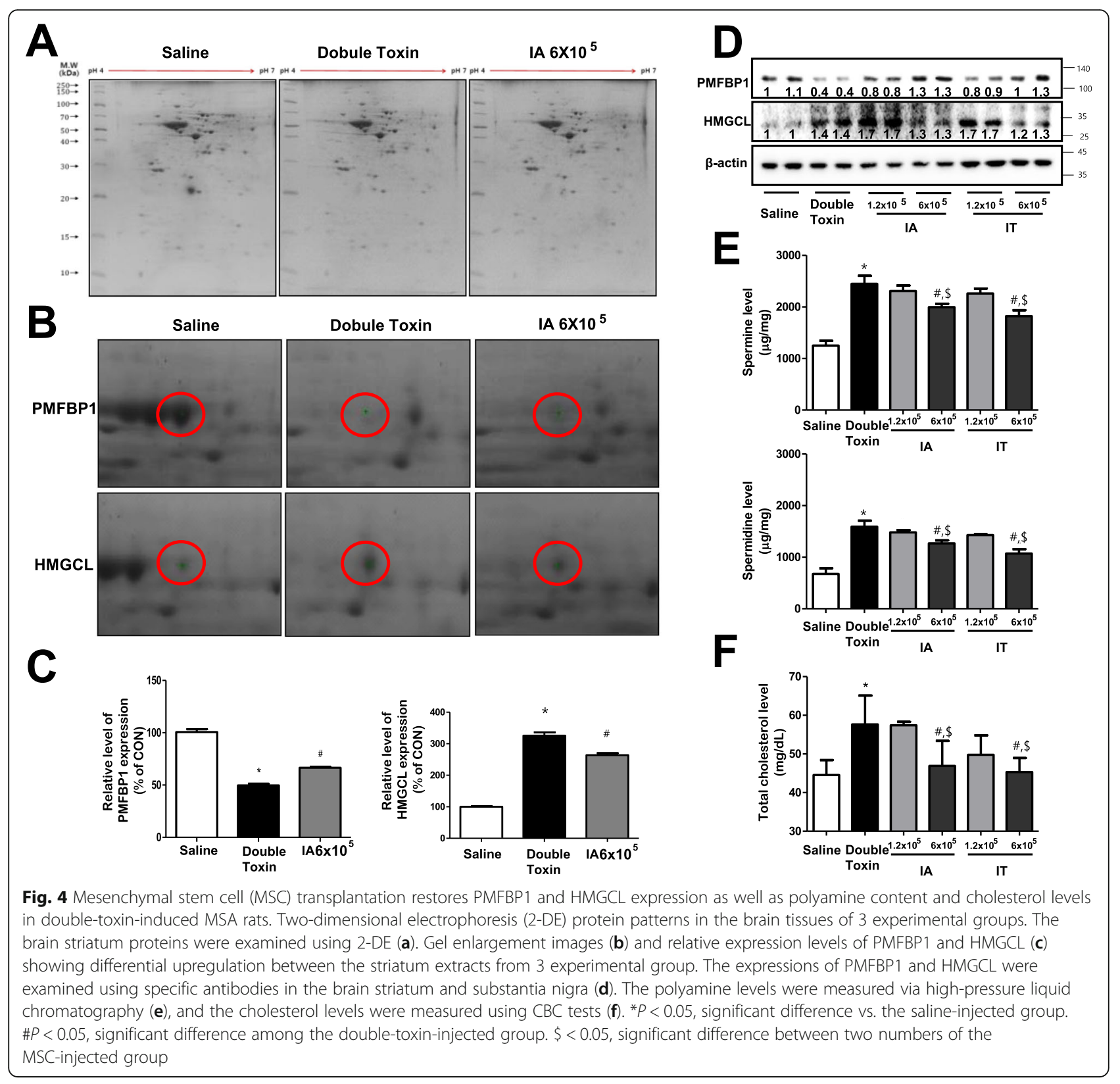

identified as representing the differential expression of key proteins in three experimental groups. Furthermore, the six spots were classified into two groups, including the increased-decreased group (upregulation due to double-toxin-induction and downregulation due to MSC transplantation; $n=5$ ) and decreasedincreased group (downregulation due to double-toxininduction and upregulation due to MSC transplantation; $n=1$ ) based on the expression level. As shown in Table 1, the five increased-decreased proteins included serum albumin precursor, 3-hydroxymethyl-3methylglutaryl-CoA lyase, the membrane-binding domain of Ctp phosphocholine cytidylyltransferase, GFAP, and alpha tubulin, whereas the decreased- increased protein was polyamine-modulated factor 1binding protein (PMFBP1) (Table 1).

MSCs restored PMFBP1 levels, but reduced HMGCL levels in double-toxin-induced MSA rats

Of these proteins, we were particularly interested in the role of PMFBP1, as it controls the synthesis of polyamines, which are critical to neuronal cell death. Moreover, we were interested in the role of HMGCL, an enzyme involved in the synthesis of cholesterol, which is critical in neurodegenerative disease. To determine the effect of MSC transplantation on the regulation of PMFBP1 and HMGCL expression, we assessed the expressions of PMFBP1 and HMGCL after MSC 
Table. 1 Differentially expressed proteins in three experimental groups

\begin{tabular}{|c|c|c|c|c|}
\hline \multirow[t]{2}{*}{ NCBI BLAST } & \multirow[t]{2}{*}{ Protein name } & \multirow[t]{2}{*}{ Mass } & \multirow{2}{*}{$\begin{array}{l}\text { Fold change } \\
\text { By double toxin }\end{array}$} & \multirow{2}{*}{$\begin{array}{l}\text { Fold change } \\
\text { By MSC }\end{array}$} \\
\hline & & & & \\
\hline gi|158138568 & Serum albumin precursor [Rattus norvegicus] & 68,758 & 2.247 & 0.517 \\
\hline gi|451770389 & $\begin{array}{l}\text { 3-hydroxymethyl-3-methylglutaryl-CoA } \\
\text { cytoplasmic [Rattus norvegicus] }\end{array}$ & 36,556 & 2.529 & 0.774 \\
\hline gi|253723061 & $\begin{array}{l}\text { Nmr structure of the membrane-binding domain } \\
\text { of Ctp phosphocholine cytidylyltransferase }\end{array}$ & 2872 & 2.115 & 0.948 \\
\hline gi|430721 & Glial fibrillary acidic protein [Rattus norvegicus] & 49,958 & 4.068 & 0.647 \\
\hline gi|223556 & tubulin alpha & 50,241 & 3.257 & 0.259 \\
\hline gi|19705509 & $\begin{array}{l}\text { Polyamine-modulated factor 1-binding protein } 1 \\
\text { [Rattus norvegicus] }\end{array}$ & 113,588 & 0.547 & 1.235 \\
\hline
\end{tabular}

transplantation. Following MSC transplantation, the PMFBP1 spots demonstrated an increased ratio (Fig. 4b). The volume ratio of this spot was significantly lower in the double-toxin-induced rats $(49.69 \%)$, as compared to the sham-controlled rats (100.67\%). Following MSC transplantation, this volume was markedly increased in the rats transplanted with MSCs $\left(6 \times 10^{5}\right.$ cells $)$ via IT injection (66.58\%) (Fig. 4c). However, the volume ratio of HMGCL spots decreased after MSC transplantation (Fig. 4c). In fact, the volume ratio of this spot was significantly higher in double-toxin-induced rats (49.69\%) than in the sham-controlled rats (100.67\%). Following MSC transplantation, this volume was markedly lower in the rats transplanted with MSCs $\left(6 \times 10^{5}\right.$ cells $)$ via IT injection (66.58\%) (Fig. 4c). To determine the expression of PMFBP1 and HMGCL in all the experimental groups, we evaluated the expression of PMFBP1 and HMGCL using western blot analysis. The expression of PMFBP1 in the striatum and substantia nigra was significantly decreased, although the expression of HMGCL was increased in double-toxin-injected rats. However, the expression of PMFBP1 and HMGCL was significantly recovered in MSC-transplanted rats as compared to that in the double-toxin-injected rats (Fig. 4d).

\section{MSC reduces polyamine content and cholesterol levels in} double-toxin-induced MSA rats

PMFBP1 regulates polyamine clearance, which is critical for neuronal cell death. Hence, we measured the polyamine content in the brain using the HPLC system. The content of spermidine and spermine was significantly increased in the double-toxin-induced rats, as compared to that in the sham-controlled rats. Following MSC transplantation, these contents were markedly decreased in the MSC-transplanted rats (Fig. 4e). HMGCL can induce cholesterol synthesis, which is critical in neurodegenerative disease; hence, we measured the cholesterol level in the brain. The total cholesterol level was significantly increased in the double-toxin-induced rats $(57.63 \pm 7.48 \mathrm{mg} / \mathrm{dL})$ as compared to the sham- controlled rats $(44.57 \pm 3.84 \mathrm{mg} / \mathrm{dL})$. Following MSC transplantation, this level was markedly decreased in the MSC-transplanted rat brain (IA $1.2 \times 10^{5}$ cells, $57.40 \pm$ $0.9 \mathrm{mg} / \mathrm{dL} ; 6 \times 10^{5}$ cells, $46.90 \pm 6.48 \mathrm{mg} / \mathrm{dL}$; IT $1.2 \times 10^{5}$ cells, $49.80 \pm 5.03 \mathrm{mg} / \mathrm{dL} ; 6 \times 10^{5}$ cells, $45.33 \pm 3.62 \mathrm{mg} /$ dL) (Fig. 4f).

\section{Knockdown of PMFBP1 and recombinant HMGCL protein reverses the protective effect of co-culture with MSCs in 6-OHDA-induced striatal neuronal cells}

We also investigated whether the changes in PMFBP1 and HMGCL expression were associated with neuronal cell death, and the modulation of their expression by MSCs is critical for the protective effects on MSA. To identify the changes in PMFBP1 and HMGCL expression on co-culture with MSCs, we evaluated the expression of PMFBP1 and HMGCL by western blot analysis. Following 6-OHDA treatment, the expression of PMFBP1 in the neuronal cells was significantly decreased (Fig. 5a), whereas the expression of HMGCL was significantly increased. However, PMFBP1 and HMGCL expressions were significantly restored (Fig. 5b) in MSCs co-cultured with neuronal cells. In order to further examine the protective mechanisms of PMFBP1 and HMGCL in MSCs against double-toxin-induced neurodegeneration, we knocked-down PMFBP1 expression via siRNA transfection in MSCs co-cultured with neuronal cells and assessed the involvement of PMFBP1 in the inflammatory and apoptotic pathways. Since the expression of PMFBP1 was found to be significantly decreased in PMFBP1-knockdown neuronal cells (Fig. 5c), it was likely that MSCs mediated the suppression of inflammatory protein (iNOS and COX2) expression (Fig. 5c). Moreover, the suppressive effect on the expression of cell death-related proteins BAX and cleaved caspase 3 as well as apoptosis were also reversed in PMFBP1-knockdown neuronal cells (Fig. 5c). Thereafter, we assessed the protective mechanisms of MSCs involving HMGCL against double-toxin-induced neurodegeneration. Accordingly, we treated MSCs co-cultured with 


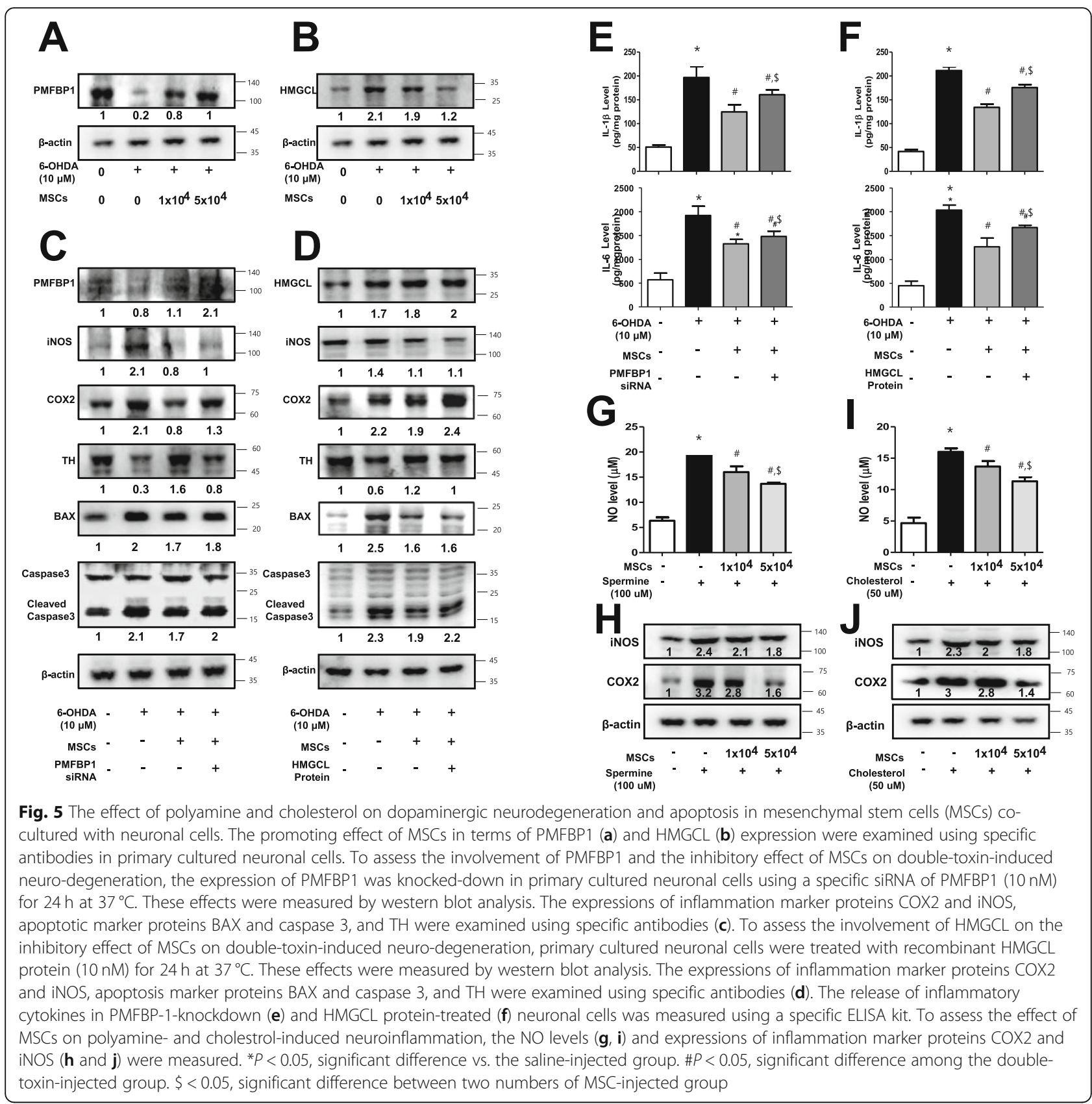

neuronal cells with the recombinant HMGCL protein and investigated the involvement of HMGCL in the inflammatory and apoptotic pathways. The MSCs mediated the expression suppression of inflammatory proteins iNOS and COX2 (Fig. 5d). Moreover, the suppressive effect on the expression of cell death-related proteins BAX and cleaved caspase 3 as well as apoptosis were also reversed in HMGCL protein-treated neuronal cells (Fig. 5d). Consistent with these protein expression data, the release of pro-inflammatory cytokines IL-1 $\beta$ and IL-6 were reversed in PMFBP1 knockdown (Fig. 5e) and HMGCL protein-treated (Fig. 5f) neuronal cells.
Co-culture with MSCs yields anti-inflammatory effects in spermine and cholesterol-induced striatal neuronal cells To further examine the protection mechanisms of MSCs against polyamine-induced neurodegeneration, we investigated the involvement of MSCs in the inflammatory and apoptotic pathways. Spermine-induced NO release (Fig. $5 \mathrm{~g}$ ) and expression of inflammatory proteins iNOS and COX2 (Fig. 5h) were reduced in a dose-dependent manner when co-cultured with MSCs. Moreover, spermine-induced cell death was also reduced by coculture with MSCs (Supplementary Fig. 4A). Thereafter, we also investigated the protection mechanisms of MSCs 
against cholesterol-induced neurodegeneration and examined the involvement of MSCs in the inflammatory and apoptotic pathways. The cholesterol-induced NO release (Fig. 5i) and the expression of inflammatory proteins iNOS and COX2 (Fig. 5j) were reduced in a dosedependent manner following co-culture with MSCs. Moreover, cholesterol-induced cell death was also reduced following co-culture with MSCs (Supplementary Fig. 4B).

\section{Discussion}

In the present study, we found clear evidence of the protective effects of MSCs on double-toxin-induced MSA. We also found that the transplantation of MSCs prevented neuronal cell death and improved behavioral disorders caused by double-toxin-induced MSA by reducing dopaminergic neurodegeneration and neuroinflammation. Several studies have reported that MSCs could be effective for the treatment of neurodegenerative diseases. The transplantation of human MSCs has been shown to reduce $A \beta$ deposition, improve memory function and alleviate $\mathrm{AD}$ pathology in an $\mathrm{AD}$ mouse model [57-59]. The co-culture of human MSCs with BV-2 in mouse microglia increased the expression of neprilysin, an $A \beta$ degradation enzyme [60]. Several studies in animal models of PD, which were induced by MPTP and 6OHDA, have indicated that MSCs can protect and regenerate damaged DA neurons [61-64]. Moreover, MSCs grafted into the striatum, intravenously or intranasally, have been shown to exert neuroprotective effects against nigrostriatal degeneration and to improve motor function in 6-OHDA-induced rats [65]. Double-toxininduced MSA leads to the loss of neuronal cells in the striatonigral regions. Moreover, upon pathological examination, MSA shows symptoms similar to that of parkinsonism. MSC therapy is effective in treating MSA patients. Finally, a clinical trial using autologous MSC transplantation $\left(4 \times 10^{7}\right.$ cells by IA injection) in patients with MSA indicated improvements in the severity of the symptoms, as well as an attenuation of the decline in cerebral glucose metabolism and gray matter density [66]. Furthermore, several studies have reported that MSCs have a potent effect on immunomodulation and neuroprotection in toxin $(\mathrm{MPTP}+3-\mathrm{NP})$-induced $(1 \times$ $10^{6}$ cells/tail vein) or transgenic MSA $\left(5 \times 10^{5}\right.$ cells/tail vein) animal models $[67,68]$. MSCs are generally transplanted through the tail vein. However, in the present study, a similar effect was observed for the transplantation of a typical dose $\left(6 \times 10^{5}\right.$ cells $)$ and a lower dose $\left(1.2 \times 10^{5}\right.$ cells $)$ via IT and IA routes. Considering the difference in the species, $1.2 \times 10^{5}$ cells is certainly a low number as compared to that used in other studies. Moreover, we confirmed the similar efficacy between IT administration, which results in less side effects, and IA administration. Furthermore, although other studies isolated MSCs from healthy people, in the present study, MSCs were isolated from patients. Thus, our findings reflect the reduced risk and increased efficacy of using MSC therapy in MSA patients.

Neuroinflammation is considered to be a direct and indirect cause of neuronal cell death and neurodegeneration. The findings of an MSA transgenic mouse model overexpressing $\alpha$-synuclein may be important in understanding the role of glial cells in neuroinflammation [69-72]. Astrogliosis was observed in all of the examined MSA mice [73]. Moreover, the deficiency of toll-like receptor 4 (TLR-4) in MSA transgenic mouse models was found to enhance the loss of nigrostriatal dopaminergic neurons [74]. These data indicated that neuroinflammation and autoimmune function were critical for the development of MSA. MSCs have been investigated as a therapeutic option for MSA, considering their capacity for differentiation as well as their immunomodulatory and anti-inflammatory properties. In the study involving a transgenic mouse model of MSA [68], the intravenous transplantation of MSCs enhanced the neuroprotective effects in the substantia nigra by regulating the proinflammatory cytokine levels in the brain. Similarly, in a double-toxin-induced MSA-P (MPTP- and 3-NPinduced MSA parkinsonism) mouse model, treatment with human MSC (hMSC) improved behavioral disorder, increased neuronal survival, and decreased astro- and microgliosis in the striatum and substantia nigra [67]. In the present study, we demonstrated that MSCs reduced neuroinflammation in a double-toxin-induced MSA model. The effect of MSCs can likely be attributed to the inhibition of the expression of the inflammatory marker proteins COX-2 and iNOS as well as the release of the pro-inflammatory cytokines IL-1 $\beta$ and IL6. In addition, the activation of microglias and astrocytes was significantly increased following the double-toxin induction, although such activation was reduced in MSCtransplanted rats. Evidence suggests that brain inflammation may contribute to the pathology of many neurodegenerative diseases, such as $\mathrm{AD}, \mathrm{PD}$, multiple sclerosis, and stroke [75-78]. Microglia and astrocytes play a major role in neuroinflammation through the release of pro-inflammatory cytokines and chemokines as well as the release of NO, which can damage neurons. Thus, these data indicate that MSCs improved behavioral disorder by reducing the neuroinflammatory responses leading to diminished neuronal cell death.

Polyamines also play a major role in the control of cerebral innate immune and inflammatory responses. Polyamines may be involved in reparative efforts of nerve tissue [29] or may play a direct role in the neurodegenerative processes [79-83]. In the brains of AD patients, the mean levels of polyamines were markedly 
increased by $70 \%$ as compared to the levels in normal brains. In addition, the polyamine concentrations were significantly increased in patients with PD and MSA as compared to those in the normal group. Although numerous studies have described the role of polyamine in the development of PD and MSA, the metabolic patterns of polyamines and their role in these diseases remain unclear. In the present study, PMFBP1 expression was significantly decreased in double-toxin-induced MSA rats, and this change led to an increase in polyamine concentration. However, the downregulated PMFBP1 expression was restored following MSC transplantation. The direct binding of polyamines to DNA and their ability to modulate DNA-protein interactions appear to be important in the molecular mechanism of polyamine in facilitating cell death $[84,85]$. In mammals, there is a direct relationship between cell death and the levels of polyamines [86]. Caspase-dependent and caspaseindependent apoptotic cell death is observed after treatment with several polyamine analogs [87]. Several studies have shown that polyamines accumulate in patients with inflammatory disease and that the metabolism of these polyamines by macrophages leads to neuron damage [88-90]. Hence, some symptoms were treated by reducing the polyamine levels [91-93]. The restoration of PMFBP1 levels by MSCs can lead to a reduction in the accumulated brain polyamines and can accordingly protect neuronal cells against polyamine-induced cell death or inflammation. In fact, we found that MSC transplantation reduced double-toxin-induced polyamine levels in the brain. Moreover, the 6-OHDA-induced neuroinflammation and cell death were significantly reduced by coculture with MSCs. However, the expressions of the neuroinflammation marker proteins COX-2 and iNOS as well as the release of pro-inflammatory cytokines were increased by knockdown of PMFBP1 expression via siRNA transfection. Moreover, the cleavage of caspase 3 and the expression of BAX were significantly increased by the treatment of PMFBP1 siRNA. Moreover, MSCs rescued spermine-induced $\mathrm{NO}$ generation and cell death. These data suggest that enhancing the effects of MSC on PMFBP1 play an important role in the antiinflammation and renewal of neurons.

HMGCL belongs to the HMG-CoA lyase family, whereas acetyl-CoA acts as a precursor in the first stage of cholesterol synthesis. These reactions occur in the cytosol and begin with the formation of 3-hydroxy-3methylglutaryl-CoA (HMG-CoA) from acetyl-CoA and acetoacetyl-CoA [94]. Mutations in the gene encoding HMGCL can lead to acetyl-CoA deficiency [95]. The role of cholesterol in neurodegenerative pathology has been reported by many studies. Intriguingly, the $\alpha$ synuclein protein contains two cholesterol-binding domains [32], and cholesterol seems to modulate $\alpha$ - synuclein aggregation. Other studies have reported that high plasma cholesterol levels lead to an increased risk of PD development $[96,97]$. In addition, high cholesterol concentration leads to the production of high levels of reactive oxygen species in the brains of patients with $\mathrm{PD}$ [98]. Moreover, the derivatives of cholesterol increase $\alpha$ synuclein levels and reduce dopamine synthesis [99, 100]. Statins (inhibitors of cholesterol synthesis) strongly reduce the aggregation of $\alpha$-synuclein in cultured neurons, whereas supplementation of the neurons with exogenous cholesterol increases $\alpha$-synuclein aggregation and reduces neuronal growth [101]. Furthermore, the treatment of a transgenic mouse model of PD with statins reduced $\alpha$-synuclein aggregation [102]. Moreover, cholesterol can induce neuroinflammation, and the metabolites of cholesterol may further contribute to neuroinflammation in the brain [103]. A recent study showed that cognitive dysfunction was induced by cholesterolinduced neuroinflammation in mice fed on a high cholesterol diet [104]. In the present study, HMGCL expression was significantly increased in double-toxin-induced MSA but was significantly reduced following MSC treatment. This decrease in HMGCL expression can reduce the accumulation of double-toxin-induced cholesterol, and can protect neuronal cells against cholesterolinduced neuroinflammation. In fact, the double toxininduced increases in cholesterol levels were significantly reduced by MSC transplantation. Moreover, in our in vitro study, co-culture with MSCs reduced the 6OHDA-induced cell death and neuroinflammation in cultured neuronal cells. However, the protective effect of MSCs against cell death and inflammation was reduced by treatment with recombinant HMGCL protein. In fact, treatment with recombinant HMGCL protein significantly increased not only the expression of neuroinflammatory markers but also the release of pro-inflammatory cytokines. In addition, the cleavage of caspase 3 and expression of BAX were also increased by treatment with recombinant HMGCL protein. Moreover, MSCs rescued cholesterol-induced cell death and reduced NO generation. These data suggest that the reduced expression of HMGCL following MSC transplantation confers a protective effect against neuroinflammation and cell death.

\section{Conclusions}

MSCs have been recently considered to have successful neuroprotective and immunomodulatory effects on neurological disorders (Supplementary Fig. 5). The significant effect of MSCs on increasing PMFBP1 expression and inhibiting HMGCL expression may represent a promising new therapeutic strategy for MSA. However, further investigation might be necessary to understand the exact mechanism in neuron-specific knockdown on in vivo animal and clinical trials in the following studies 
of MSA patients, although the knockdown experiments were to assess the involvement of PMFBP1 in neuron for the inhibitory effect of MSCs on double-toxininduced neuro-degeneration. Taken together, our data suggest that human bone marrow-derived MSCs can improve dopaminergic neuro-degeneration in MSA by reducing polyamine- and cholesterol-modulated neuroinflammation.

\section{Supplementary information}

Supplementary information accompanies this paper at https://doi.org/10. 1186/s13287-020-01590-1.

Additional file 1: Supplementary figure 1 Mesenchymal stem cell (MSC) transplantation ameliorates double-toxin-induced neural apoptosis. The effect of MSC transplantation on neuronal apoptosis was measured by TUNEL assay. Detection of apoptotic cell death in the brains as shown by TUNEL staining $(n=3)$. Supplementary figure 2 MSC transplantation ameliorates double-toxin-induced neuroinflammation. Effect of MSC transplantation on neuroinflammation by western blot analysis and ELISA. Expression of iNOS and COX2 was also examined by specific antibodies in the brain striatum and substantia nigra (A). The release of inflammatory cytokines IL-1 $\beta$ and IL- 6 in the rat brain striatum and substantia nigra was measured by a specific ELISA kit (B). Each value is presented as mean \pm SD of 10 rat. ${ }^{*}, p<0.05$ : significant difference from saline-injected groups and \#, $p<0.05$ : significant difference between the double-toxin-injection groups. Supplementary figure 3 MSC transplantation increases neutrophils but reduces WBC. The cell numbers of neutrophils $(A)$ and WBC (B) were measured using $C B C$ tests. ${ }^{*}, P<0.05$ : significant difference vs. the salineinjected group. \#, $\mathrm{P}<0.05$ : significant difference among the double-toxininjected groups. $\$<0.05$ : significant difference between two numbers of the MSC-injected groups. Supplementary figure 4 MSC co-culture ameliorates polyamine and cholesterol-induced neuronal cell death. To assess the effects of MSCs on polyamines (A) and cholesterols (B)-induced neuronal cell death, cell viability was measured by the MTT assay. ${ }^{*}, p<0.05$ : significant difference from the non-treated neuronal cells. \#, $p<0.05$ : significant difference after treatment with spermine $(100 \mu \mathrm{M})$ or cholesterol $(50 \mu \mathrm{M})$ in neuronal cells. $\$, p<0.05$ : significant difference between the neuronal cells co-treated with MSCs. Supplementary figure 5 Flowchart for the inhibitory effect of MSCs on double-toxin-induced dopaminergic neurodegenerative MSA.

\section{Abbreviations}

6-OHDA: 6-Hydroxydopamine hydrochloride; AD: Alzheimer's disease; DAPI: Dihydrochloride; GFAP: Glial fibrillary acidic protein expression; HMGCL: 3-Hydroxymethyl-3-methylglutaryl-CoA lyase; LPS: Lipopolysaccharide; MSA: Multiple system atrophy; MSCs: Mesenchymal stem cells; PD: Parkinson's disease; PMFBP1: Polyamine modulating factorbinding protein 1; SSAT1: Spermidine/spermine N1-acetyltransferase; TUNEL: Terminal deoxynucleotidyl transferase-mediated FITC-dUDP nick-end labeling

\section{Acknowledgements}

Not applicable.

\section{Authors' contributions}

KRP contributed to the conceptualization, resources, investigation, writing, and revision. $\mathrm{CJH}$ contributed to the investigation and writing. HMY contributed to the conceptualization, resources, writing, and revision. IJY contributed to the software and validation. DYC, PHP, HSK, JTL, YSJ, and SBH contributed to the resources. JTH contributed to the conceptualization, project administration, resources, writing, and supervision. All authors read and approved the final manuscript.

\section{Funding}

This work was supported by a grant from the National Research Foundation of Korea (NRF), funded by the Korean Government (MSIP; MRC,
2017R1A5A2015541, 2018R1D1A1B07043282) and by the functional districts of the science belt support program through the Ministry of Science, ICT, and Future Planning (2015 K000248)

\section{Availability of data and materials}

Not applicable.

\section{Ethics approval and consent to participate}

A total of 60 adult male Wistar rats weighing 200-250 g were purchased from DBL (Seoul, Republic of Korea) and were maintained in accordance with the guidelines of the National Institute of Toxicological Research and Korea Food and Drug Administration for the humane care and use of laboratory animals. Animals were housed in a room that was automatically maintained at $21-25^{\circ} \mathrm{C}$, with a relative humidity of $45-65 \%$ and controlled 12-h light/dark cycle. All experimental procedures in the present study were approved by the IACUC of Chungbuk National University (approval number CBNUA-144-1001-01).

\section{Consent for publication}

Not applicable.

\section{Competing interests}

The authors declare that they have no competing interests.

\section{Author details}

${ }^{1}$ Department of Oral and Maxillofacial Pathology, School of Dentistry, Kyung Hee University, Seoul 02453, Republic of Korea. ${ }^{2}$ College of Pharmacy and Medical Research Center, Chungbuk National University, 194-31, Osongsangmyeong1-ro, Heungdeok-gu, Cheongju, Chungbuk 361-951, Republic of Korea. ${ }^{3}$ College of Pharmacy, Yeungnam University, 280, Daehak-ro, Gyeongsan, Gyeongbuk 712-749, Republic of Korea. ${ }^{4}$ Corestem Inc, Pangyo-ro 255 beon-gil, Bundang-gu, Seongnam-si, Gyeonggi 13486, Republic of Korea. ${ }^{5}$ College of Pharmacy, Pusan National University, Geumjeong-gu, Busan, Republic of Korea.

Received: 4 October 2019 Revised: 11 January 2020 Accepted: 6 February 2020 Published online: 04 March 2020

\section{References}

1. Wenning GK, Jellinger KA. The role of alpha-synuclein in the pathogenesis of multiple system atrophy. Acta Neuropathol. 2005;109(2):129-40.

2. Wenning GK, Colosimo C, Geser F, Poewe W. Multiple system atrophy. The Lancet Neurol. 2004;3(2):93-103.

3. Wenning GK, Granata R, Laboyrie PM, Quinn NP, Jenner P, Marsden CD. Reversal of behavioural abnormalities by fetal allografts in a novel rat model of striatonigral degeneration. Mov Disord. 1996;11(5):522-32.

4. Nombela-Arrieta C, Ritz J, Silberstein LE. The elusive nature and function of mesenchymal stem cells. Nat Rev Mol Cell Biol. 2011;12(2):126-31.

5. Barlow S, Brooke G, Chatterjee K, Price G, Pelekanos R, Rossetti T, et al. Comparison of human placenta- and bone marrow-derived multipotent mesenchymal stem cells. Stem Cells Dev. 2008;17(6):1095-107.

6. Brooke G, Rossetti T, Pelekanos R, llic N, Murray P, Hancock S, et al. Manufacturing of human placenta-derived mesenchymal stem cells for clinical trials. Br J Haematol. 2009;144(4):571-9.

7. Tran TC, Kimura K, Nagano M, Yamashita T, Ohneda K, Sugimori H, et al. Identification of human placenta-derived mesenchymal stem cells involved in re-endothelialization. J Cell Physiol. 2011;226(1):224-35.

8. Chu DT, Nguyen Thi Phuong T, Tien NLB, Tran DK, Minh LB, Thanh W, et al. Adipose Tissue Stem Cells for Therapy: An Update on the Progress of Isolation, Culture, Storage, and Clinical Application. J Clin Med. 2019;8(7):119.

9. Rogne M, Chu DT, Kuntziger TM, Mylonakou MN, Collas P, Tasken K. OPA1anchored PKA phosphorylates perilipin 1 on S522 and S497 in adipocytes differentiated from human adipose stem cells. Mol Biol Cell. 2018;29(12): 1487-501.

10. Khoo ML, Tao H, Meedeniya AC, Mackay-Sim A, Ma DD. Transplantation of neuronal-primed human bone marrow mesenchymal stem cells in hemiparkinsonian rodents. PLoS One. 2011;6(5):e19025.

11. Bobkova NV, Poltavtseva RA, Samokhin AN, Sukhikh GT. Therapeutic effect of mesenchymal multipotent stromal cells on memory in animals with Alzheimer-type neurodegeneration. Bull Exp Biol Med. 2013;156(1):119-21. 
12. Naaldijk Y, Jager C, Fabian C, Leovsky C, Bluher A, Rudolph L, et al. Effect of systemic transplantation of bone marrow-derived mesenchymal stem cells on neuropathology markers in APP/PS1 Alzheimer mice. Neuropathol Appl Neurobiol. 2016;43(4):299-314.

13. Shin JY, Park HJ, Kim HN, Oh SH, Bae JS, Ha HJ, et al. Mesenchymal stem cells enhance autophagy and increase beta-amyloid clearance in Alzheimer disease models. Autophagy. 2014;10(1):32-44.

14. Tanabe $\mathrm{S}$. Role of mesenchymal stem cells in cell life and their signaling. World J Stem cells. 2014;6(1):24-32.

15. Chinnadurai R, Copland IB, Patel SR, Galipeau J. IDO-independent suppression of $\mathrm{T}$ cell effector function by IFN-gamma-licensed human mesenchymal stromal cells. J Immunol. 2014;192(4):1491-501.

16. Di Nicola M, Carlo-Stella C, Magni M, Milanesi M, Longoni PD, Matteucci P, et al. Human bone marrow stromal cells suppress T-lymphocyte proliferation induced by cellular or nonspecific mitogenic stimuli. Blood. 2002;99(10):3838-43.

17. Tse WT, Pendleton JD, Beyer WM, Egalka MC, Guinan EC. Suppression of allogeneic T-cell proliferation by human marrow stromal cells: implications in transplantation. Transplantation. 2003;75(3):389-97.

18. Kyurkchiev D, Bochev I, Ivanova-Todorova E, Mourdjeva M, Oreshkova T, Belemezova K, et al. Secretion of immunoregulatory cytokines by mesenchymal stem cells. World J Stem Cells. 2014;6(5):552-70.

19. van Buul GM, Villafuertes E, Bos PK, Waarsing JH, Kops N, Narcisi R, et al. Mesenchymal stem cells secrete factors that inhibit inflammatory processes in short-term osteoarthritic synovium and cartilage explant culture. Osteoarthr Cartil. 2012;20(10):1186-96.

20. Lee PH, Kim JW, Bang OY, Ahn YH, Joo IS, Huh K. Autologous mesenchymal stem cell therapy delays the progression of neurological deficits in patients with multiple system atrophy. Clin Pharmacol Ther. 2008;83(5):723-30.

21. Venkataramana NK, Kumar SK, Balaraju S, Radhakrishnan RC, Bansal A, Dixit A, et al. Open-labeled study of unilateral autologous bone-marrow-derived mesenchymal stem cell transplantation in Parkinson's disease. Transl Res. 2010;155(2):62-70.

22. Karussis D, Karageorgiou C, Vaknin-Dembinsky A, Gowda-Kurkalli B, Gomor JM, Kassis I, et al. Safety and immunological effects of mesenchymal stem cell transplantation in patients with multiple sclerosis and amyotrophic lateral sclerosis. Arch Neurol. 2010;67(10):1187-94.

23. Kim HY, Kim H, Oh KW, Oh SI, Koh SH, Baik W, et al. Biological markers of mesenchymal stromal cells as predictors of response to autologous stem cell transplantation in patients with amyotrophic lateral sclerosis: an investigator-initiated trial and in vivo study. Stem Cells. 2014;32(10):2724-31.

24. Cummings JL, Morstorf T, Zhong K. Alzheimer's disease drug-development pipeline: few candidates, frequent failures. Alzheimers Res Ther. 2014;6(4):37.

25. Zahedi K, Bissler JJ, Wang Z, Josyula A, Lu L, Diegelman P, et al. Spermidine/ spermine N1-acetyltransferase overexpression in kidney epithelial cells disrupts polyamine homeostasis, leads to DNA damage, and causes G2 arrest. Am J Physiol Cell Physiol. 2007;292(3):C1204-15.

26. Silva MA, Klafke JZ, Rossato MF, Gewehr C, Guerra GP, Rubin MA, et al. Role of peripheral polyamines in the development of inflammatory pain. Biochem Pharmacol. 2011;82(3):269-77.

27. Puntambekar SS, Davis DS, Hawel L 3rd, Crane J, Byus CV, Carson MJ. LPSinduced CCL2 expression and macrophage influx into the murine central nervous system is polyamine-dependent. Brain Behav Immun. 2011;25(4):629-39.

28. Gobert AP, Cheng Y, Wang JY, Boucher JL, lyer RK, Cederbaum SD, et al. Helicobacter pylori induces macrophage apoptosis by activation of arginase II. J Immunol. 2002;168(9):4692-700.

29. Soulet D, Rivest S. Polyamines play a critical role in the control of the innate immune response in the mouse central nervous system. J Cell Biol. 2003; 162(2):257-68.

30. Karouzakis E, Gay RE, Gay S, Neidhart M. Increased recycling of polyamines is associated with global DNA hypomethylation in rheumatoid arthritis synovial fibroblasts. Arthritis Rheum. 2012;64(6):1809-17.

31. Montgomery C, Pei Z, Watkins PA, Miziorko HM. Identification and characterization of an extramitochondrial human 3-hydroxy-3methylglutaryl-CoA lyase. J Biol Chem. 2012;287(40):33227-36.

32. Fantini J, Carlus D, Yahi N. The fusogenic tilted peptide (67-78) of alphasynuclein is a cholesterol binding domain. Biochim Biophys Acta. 2011; 1808(10):2343-51.

33. Kojro E, Gimpl G, Lammich S, Marz W, Fahrenholz F. Low cholesterol stimulates the nonamyloidogenic pathway by its effect on the alpha -secretase ADAM 10. Proc Natl Acad Sci U S A. 2001;98(10):5815-20.
34. Porter FD, Herman GE. Malformation syndromes caused by disorders of cholesterol synthesis. J Lipid Res. 2011;52(1):6-34.

35. Simons M, Keller P, De Strooper B, Beyreuther K, Dotti CG, Simons K. Cholesterol depletion inhibits the generation of beta-amyloid in hippocampal neurons. Proc Natl Acad Sci U S A. 1998;95(11):6460-4.

36. Valenza $M$, Rigamonti $D$, Goffredo $D$, Zuccato $C$, Fenu $S$, Jamot $L$, et al. Dysfunction of the cholesterol biosynthetic pathway in Huntington's disease. J Neurosci. 2005;25(43):9932-9.

37. Bodovitz S, Klein WL. Cholesterol modulates alpha-secretase cleavage of amyloid precursor protein. J Biol Chem. 1996;271(8):4436-40.

38. Blood pressure, cholesterol, and stroke in eastern Asia. Eastern Stroke and Coronary Heart Disease Collaborative Research Group. Lancet. 1998; 352(9143):1801-7.

39. Subramanian S, Han CY, Chiba T, McMillen TS, Wang SA, Haw A 3rd, et al. Dietary cholesterol worsens adipose tissue macrophage accumulation and atherosclerosis in obese LDL receptor-deficient mice. Arterioscler Thromb Vasc Biol. 2008;28(4):685-91.

40. Hotamisligil GS. Inflammation and metabolic disorders. Nature. 2006; 444(7121):860-7.

41. Li H, Li H, Guo H, Liu F. Cholesterol suppresses adipocytic differentiation of mouse adipose-derived stromal cells via PPARgamma2 signaling. Steroids. 2013;78(5):454-61

42. Morrison CD, Pistell PJ, Ingram DK, Johnson WD, Liu Y, Fernandez-Kim SO, et al. High fat diet increases hippocampal oxidative stress and cognitive impairment in aged mice: implications for decreased Nrf2 signaling. J Neurochem. 2010;114(6):1581-9.

43. Zhang X, Dong F, Ren J, Driscoll MJ, Culver B. High dietary fat induces NADPH oxidase-associated oxidative stress and inflammation in rat cerebral cortex. Exp Neurol. 2005;191(2):318-25.

44. Lewis DK, Bake S, Thomas K, Jezierski MK, Sohrabji F. A high cholesterol diet elevates hippocampal cytokine expression in an age and estrogendependent manner in female rats. J Neuroimmunol. 2010;223(1-2):31-8.

45. Ullah M, Stich S, Haupl T, Eucker J, Sittinger M, Ringe J. Reverse differentiation as a gene filtering tool in genome expression profiling of adipogenesis for fat marker gene selection and their analysis. PLoS One. 2013:8(7):e69754

46. Jadasz JJ, Kremer D, Gottle P, Tzekova N, Domke J, Rivera FJ, et al. Mesenchymal stem cell conditioning promotes rat oligodendroglial cell maturation. PLoS One. 2013;8(8):e71814.

47. Cousins MS, Salamone JD. Skilled motor deficits in rats induced by ventrolateral striatal dopamine depletions: behavioral and pharmacological characterization. Brain Res. 1996;732(1-2):186-94.

48. Kirik D, Rosenblad C, Bjorklund A. Characterization of behavioral and neurodegenerative changes following partial lesions of the nigrostriatal dopamine system induced by intrastriatal 6-hydroxydopamine in the rat. Exp Neurol. 1998;152(2):259-77.

49. Chang JW, Wachtel SR, Young D, Kang UJ. Biochemical and anatomical characterization of forepaw adjusting steps in rat models of Parkinson's disease: studies on medial forebrain bundle and striatal lesions. Neuroscience. 1999;88(2):617-28.

50. Choi DY, Lee MK, Hong JT. Lack of CCR5 modifies glial phenotypes and population of the nigral dopaminergic neurons, but not MPTP-induced dopaminergic neurodegeneration. Neurobiol Dis. 2012:49C:159-68.

51. Fernagut $P O$, Diguet $E$, Labattu $B$, Tison F. A simple method to measure stride length as an index of nigrostriatal dysfunction in mice. J Neurosci Methods. 2002;113(2):123-30.

52. Lee Y-J, Choi D-Y, Choi IS, Kim KH, Kim YH, Kim HM, et al. Inhibitory effect of 4-O-methylhonokiol on lipopolysaccharide-induced neuroinflammation, amyloidogenesis and memory impairment via inhibition of nuclear factorkappaB in vitro and in vivo models. J Neuroinflammation. 2012;9:35.

53. Yun HM, Jin P, Park KR, Hwang J, Jeong HS, Kim EC, et al. Thiacremonone potentiates anti-oxidant effects to improve memory dysfunction in an APP/ PS1 transgenic mice model. Mol Neurobiol. 2016;53(4):2409-20.

54. Yun HM, Park KR, Kim EC, Hong JT. PRDX6 controls multiple sclerosis by suppressing inflammation and blood brain barrier disruption. Oncotarget. 2015:6(25):20875-84.

55. Choi D-Y, Liu M, Hunter RL, Cass WA, Pandya JD, Sullivan PG, et al. Striatal Neuroinflammation promotes parkinsonism in rats. PLoS One. 2009;4(5):e5482.

56. Yun HM, Kim JA, Hwang CJ, Jin P, Baek MK, Lee JM, et al. Neuroinflammatory and Amyloidogenic activities of IL-32beta in Alzheimer's disease. Mol Neurobiol. 2015;52(1):341-52. 
57. Lee HJ, Lee JK, Lee H, Carter JE, Chang JW, Oh W, et al. Human umbilical cord blood-derived mesenchymal stem cells improve neuropathology and cognitive impairment in an Alzheimer's disease mouse model through modulation of neuroinflammation. Neurobiol Aging. 2012;33(3):588-602.

58. Li M, Guo K, Ikehara S. Stem cell treatment for Alzheimer's disease. Int J Mol Sci. 2014;15(10):19226-38.

59. Xie ZH, Liu Z, Zhang XR, Yang H, Wei LF, Wang Y, et al. Wharton's jellyderived mesenchymal stem cells alleviate memory deficits and reduce amyloid-beta deposition in an APP/PS1 transgenic mouse model. Clin Exp Med. 2016;16(1):89-98.

60. Kim JY, Kim DH, Kim JH, Lee D, Jeon HB, Kwon SJ, et al. Soluble intracellular adhesion molecule-1 secreted by human umbilical cord blood-derived mesenchymal stem cell reduces amyloid-beta plaques. Cell Death Differ. 2012;19(4):680-91.

61. Wang F, Yasuhara T, Shingo T, Kameda M, Tajiri N, Yuan WJ, et al. Intravenous administration of mesenchymal stem cells exerts therapeutic effects on parkinsonian model of rats: focusing on neuroprotective effects of stromal cell-derived factor-1alpha. BMC Neurosci. 2010;11:52.

62. Kim YJ, Park HJ, Lee G, Bang OY, Ahn YH, Joe E, et al. Neuroprotective effects of human mesenchymal stem cells on dopaminergic neurons through anti-inflammatory action. Glia. 2009;57(1):13-23.

63. Cova L, Bossolasco P, Armentero MT, Diana V, Zennaro E, Mellone M, et al. Neuroprotective effects of human mesenchymal stem cells on neural cultures exposed to 6-hydroxydopamine: implications for reparative therapy in Parkinson's disease. Apoptosis. 2012;17(3):289-304.

64. Park HJ, Shin JY, Kim HN, Oh SH, Lee PH. Neuroprotective effects of mesenchymal stem cells through autophagy modulation in a parkinsonian model. Neurobiol Aging. 2014;35(8):1920-8.

65. Blandini F, Cova L, Armentero MT, Zennaro E, Levandis G, Bossolasco P, et al. Transplantation of undifferentiated human mesenchymal stem cells protects against 6-hydroxydopamine neurotoxicity in the rat. Cell Transplant. 2010;19(2):203-17.

66. Lee PH, Lee JE, Kim HS, Song SK, Lee HS, Nam HS, et al. A randomized tria of mesenchymal stem cells in multiple system atrophy. Ann Neurol. 2012; 72(1):32-40.

67. Park HJ, Bang G, Lee BR, Kim HO, Lee PH. Neuroprotective effect of human mesenchymal stem cells in an animal model of double toxin-induced multiple system atrophy parkinsonism. Cell Transplant. 2011;20(6):827-35.

68. Stemberger S, Jamnig A, Stefanova N, Lepperdinger G, Reindl M, Wenning GK. Mesenchymal stem cells in a transgenic mouse model of multiple system atrophy: immunomodulation and neuroprotection. PLoS One. 2011; 6(5):e19808.

69. Spillantini MG. Parkinson's disease, dementia with Lewy bodies and multiple system atrophy are alpha-synucleinopathies. Parkinsonism Relat Disord. 1999:5(4):157-62.

70. Dickson DW, Lin W, Liu WK, Yen SH. Multiple system atrophy: a sporadic synucleinopathy. Brain Pathol. 1999;9(4):721-32.

71. Papp MI, Kahn JE, Lantos PL. Glial cytoplasmic inclusions in the CNS of patients with multiple system atrophy (striatonigral degeneration, olivopontocerebellar atrophy and shy-Drager syndrome). J Neurol Sci. 1989; 94(1-3):79-100

72. Wakabayashi K, Yoshimoto M, Tsuji S, Takahashi H. Alpha-synuclein immunoreactivity in glial cytoplasmic inclusions in multiple system atrophy. Neurosci Lett. 1998;249(2-3):180-2.

73. Watanabe $H$, Saito $Y$, Terao S, Ando T, Kachi T, Mukai E, et al. Progression and prognosis in multiple system atrophy: an analysis of 230 Japanese patients. Brain. 2002;125(Pt 5):1070-83.

74. Stefanova N, Fellner L, Reindl M, Masliah E, Poewe W, Wenning GK. Toll-like receptor 4 promotes alpha-synuclein clearance and survival of nigral dopaminergic neurons. Am J Pathol. 2011;179(2):954-63.

75. van Groen T, Miettinen P, Kadish I. Transgenic AD model mice, effects of potential anti-AD treatments on inflammation, and pathology. J Alzheimers Dis. 2011;24(2):301-13.

76. Ransohoff RM. Mechanisms of inflammation in MS tissue: adhesion molecules and chemokines. J Neuroimmunol. 1999;98(1):57-68.

77. Jeitner TM, Kalogiannis M, Krasnikov BF, Gomolin I, Peltier MR, Moran GR. Linking inflammation and Parkinson disease: Hypochlorous acid generates Parkinsonian poisons. Toxicol Sci. 2016;153(2):410.

78. del Zoppo G, Ginis I, Hallenbeck JM, ladecola C, Wang X, Feuerstein GZ. Inflammation and stroke: putative role for cytokines, adhesion molecules and iNOS in brain response to ischemia. Brain Pathol. 2000;10(1):95-112.
79. Slotkin TA, Bartolome J. Role of ornithine decarboxylase and the polyamines in nervous system development: a review. Brain Res Bull. 1986;17(3):307-20.

80. Dempsey RJ, Roy MW, Cowen DE, Combs DJ. Polyamine inhibition preserves somatosensory evoked potential activity after transient cerebral ischaemia. Neurol Res. 1988;10(3):141-4.

81. Sparapani M, Dall'Olio R, Gandolfi O, Ciani E, Contestabile A. Neurotoxicity of polyamines and pharmacological neuroprotection in cultures of rat cerebellar granule cells. Exp Neurol. 1997;148(1):157-66.

82. Dogan A, Rao AM, Hatcher J, Rao VL, Baskaya MK, Dempsey RJ. Effects of MDL 72527, a specific inhibitor of polyamine oxidase, on brain edema, ischemic injury volume, and tissue polyamine levels in rats after temporary middle cerebral artery occlusion. J Neurochem. 1999;72(2):765-70.

83. Dogan A, Rao AM, Baskaya MK, Hatcher J, Temiz C, Rao VL, et al. Contribution of polyamine oxidase to brain injury after trauma. J Neurosurg. 1999:90(6):1078-82.

84. Stefanelli C, Stanic I, Zini M, Bonavita F, Flamigni F, Zambonin L, et al. Polyamines directly induce release of cytochrome $\mathrm{c}$ from heart mitochondria. Biochem J. 2000;347(Pt 3):875-80.

85. Thomas T, Shah N, Klinge CM, Faaland CA, Adihkarakunnathu S, Gallo MA, et al. Polyamine biosynthesis inhibitors alter protein-protein interactions involving estrogen receptor in MCF-7 breast cancer cells. J Mol Endocrinol. 1999;22(2):131-9.

86. Chaturvedi $\mathrm{R}$, Cheng Y, Asim M, Bussiere Fl, Xu H, Gobert AP, et al. Induction of polyamine oxidase 1 by helicobacter pylori causes macrophage apoptosis by hydrogen peroxide release and mitochondrial membrane depolarization. J Biol Chem. 2004;279(38):40161-73.

87. Casero RA Jr, Marton $\sqcup$. Targeting polyamine metabolism and function in cancer and other hyperproliferative diseases. Nat Rev Drug Discov. 2007;6(5):373-90.

88. Flescher E, Bowlin TL, Talal N. Regulation of IL-2 production by mononuclear cells from rheumatoid arthritis synovial fluids. Clin Exp Immunol. 1992;87(3):435-7

89. Yukioka K, Wakitani S, Yukioka M, Furumitsu Y, Shichikawa K, Ochi T, et al. Polyamine levels in synovial tissues and synovial fluids of patients with rheumatoid arthritis. J Rheumatol. 1992;19(5):689-92.

90. Flescher E, Bowlin TL, Ballester A, Houk R, Talal N. Increased polyamines may downregulate interleukin 2 production in rheumatoid arthritis. J Clin Invest. 1989;83(4):1356-62.

91. Nesher G, Moore TL. The in vitro effects of methotrexate on peripheral blood mononuclear cells. Modulation by methyl donors and spermidine. Arthritis Rheum. 1990;33(7):954-9.

92. Nesher G, Osborn TG, Moore TL. In vitro effects of methotrexate on polyamine levels in lymphocytes from rheumatoid arthritis patients. Clin Exp Rheumatol. 1996:14(4):395-9.

93. Furumitsu Y, Yukioka K, Kojima A, Yukioka M, Shichikawa K, Ochi T, et al. Levels of urinary polyamines in patients with rheumatoid arthritis. $J$ Rheumatol. 1993;20(10):1661-5.

94. Holstein SA, Hohl RJ. Isoprenoids: remarkable diversity of form and function. Lipids. 2004;39(4):293-309.

95. Aoyama $Y$, Yamamoto $T$, Sakaguchi $N$, Ishige $M$, Tanaka $T$, Ichihara $T$, et al. Application of multiplex ligation-dependent probe amplification, and identification of a heterozygous Alu-associated deletion and a uniparental disomy of chromosome 1 in two patients with 3-hydroxy-3-methylglutarylCoA lyase deficiency. Int J Mol Med. 2015;35(6):1554-60.

96. Sohmiya M, Tanaka M, Tak NW, Yanagisawa M, Tanino Y, Suzuki Y, et al. Redox status of plasma coenzyme Q10 indicates elevated systemic oxidative stress in Parkinson's disease. J Neurol Sci. 2004;223(2):161-6.

97. Scigliano G, Musicco M, Soliveri P, Piccolo I, Ronchetti G, Girotti F. Reduced risk factors for vascular disorders in Parkinson disease patients: a casecontrol study. Stroke. 2006;37(5):1184-8.

98. Huang X, Chen H, Miller WC, Mailman RB, Woodard JL, Chen PC, et al. Lower low-density lipoprotein cholesterol levels are associated with Parkinson's disease. Mov Disord. 2007:22(3):377-81.

99. Rantham Prabhakara JP, Feist G, Thomasson S, Thompson A, Schommer E, Ghribi O. Differential effects of 24-hydroxycholesterol and 27hydroxycholesterol on tyrosine hydroxylase and alpha-synuclein in human neuroblastoma SH-SY5Y cells. J Neurochem. 2008:107(6):1722-9.

100. Marwarha G, Rhen T, Schommer T, Ghribi O. The oxysterol 27hydroxycholesterol regulates alpha-synuclein and tyrosine hydroxylase expression levels in human neuroblastoma cells through modulation of liver $X$ receptors and estrogen receptors--relevance to Parkinson's disease. J Neurochem. 2011;119(5):1119-36. 
101. Bar-On P, Crews L, Koob AO, Mizuno H, Adame A, Spencer B, et al. Statins reduce neuronal alpha-synuclein aggregation in in vitro models of Parkinson's disease. J Neurochem. 2008;105(5):1656-67.

102. Crews L, Mizuno H, Desplats P, Rockenstein E, Adame A, Patrick C, et al. Alpha-synuclein alters Notch-1 expression and neurogenesis in mouse embryonic stem cells and in the hippocampus of transgenic mice. J Neurosci. 2008;28(16):4250-60.

103. Kotti TJ, Ramirez DM, Pfeiffer BE, Huber KM, Russell DW. Brain cholesterol turnover required for geranylgeraniol production and learning in mice. Proc Natl Acad Sci U S A. 2006;103(10):3869-74.

104. Thirumangalakudi L, Prakasam A, Zhang R, Bimonte-Nelson H, Sambamurti K, Kindy MS, et al. High cholesterol-induced neuroinflammation and amyloid precursor protein processing correlate with loss of working memory in mice. J Neurochem. 2008;106(1):475-85.

\section{Publisher's Note}

Springer Nature remains neutral with regard to jurisdictional claims in published maps and institutional affiliations.

Ready to submit your research? Choose BMC and benefit from:

- fast, convenient online submission

- thorough peer review by experienced researchers in your field

- rapid publication on acceptance

- support for research data, including large and complex data types

- gold Open Access which fosters wider collaboration and increased citations

- maximum visibility for your research: over $100 \mathrm{M}$ website views per year

At BMC, research is always in progress.

Learn more biomedcentral.com/submissions 